Overview on radon measurements in

\title{
Overview on radon measurements in Arctic glacier waters
}

\section{A. Kies ${ }^{1}$, O. Hengesch ${ }^{1}$, Z. Tosheva ${ }^{1}$, A. P. Nawrot ${ }^{2}$, and J. Jania ${ }^{3}$}

${ }^{1}$ Laboratoire Physique des Radiations (LPR), University of Luxembourg, Luxembourg ${ }^{2}$ Institute of Geophysics Polish Academy of Sciences, Leading National Research Centre (KNOW), Warsaw, Poland

${ }^{3}$ Faculty of Earth Sciences, University of Silesia - Centre for Polar Studies, Poland

Received: 23 February 2015 - Accepted: 2 March 2015 - Published: 26 March 2015

Correspondence to: A. Kies (antoine.kies@uni.lu)

Published by Copernicus Publications on behalf of the European Geosciences Union.

\section{Arctic glacier waters}

A. Kies et al.

\section{Title Page}

Abstract

Introduction

Conclusions

References

Tables

Figures

14

\section{4}

Back

\section{Close}

Printer-friendly Version

Interactive Discussion 


\section{Abstract}

We present a possibility to investigate the presence of the subglacial component in waters supplied by glacierized basins in introducing radioactive isotope measurements, in combination with more classical parameters like temperature and electrical conduc5 tivity. Among the natural radioactive elements the most promising is the noble gas radon isotope ${ }^{222} \mathrm{Rnv}$. With a half-life of 3.8 days, it constitutes a short time tracer and also allows continuous measurements. In waters drained out from a target landbased Svalbard glacier, radon levels show surprisingly high values up to $33 \mathrm{~Bq} \mathrm{~L}^{-1}$ in the accumulation season. In the ablation period varying radon concentrations can be linked to

mixing of waters from different origins, roughly supraglacial (meltwater and rain water), englacial and subglacial. Only water recently in close contact with bedrock or sediments can be charged with radon. Results from several years of radon measurements on Werenskiold glacier, in ablation and accumulation seasons, are presented and discussed. The results of continuous measurements give proxy information on drainage footpaths and the style and system of the draining of glaciers. They enable to distinguish the presence of a subglacial component in water flowing from the glacier system in different seasons of the year and thus are a step towards the indication of the prevailing type of glacier drainage during summer and winter seasons.

\section{Introduction} crease of ice thickness is a typical feature of almost all ice bodies in southern Spitsbergen. In this period of global glacier retreat, understanding the processes whereby meltwater drains from beneath glaciers is a central problem (Boulton et al., 2007). To understand the changes and evolution of a glacier's state, studies based on the melt25 water drainage within glacier systems are very important (Wadham et al., 1998). Water plays a dominant role in glacial dynamic processes. The style of a drainage system is
Overview on radon measurements in Arctic glacier waters

A. Kies et al.

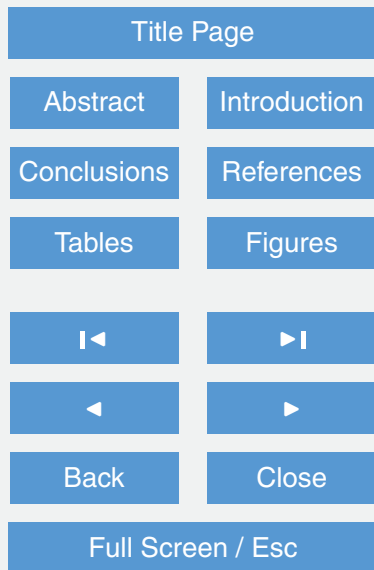

Printer-friendly Version

Interactive Discussion 
related to enhancement of basal sliding (associated to dispersed sublacial drainage) or to slow down when drainage is channelized (Raymond and al., 1995). Moreover, the erosional, depositional and environmental significance of meltwaters and associated fluvioglacial processes cannot be overemphasized (Eyles, 2006). For these reasons, 5 recognition between domination of drainage type within and underneath of glaciers using a relatively handy field method is important. Different ionic species are acquired by contact during water flow through the glacier drainage system and contribute to the increased electrical conductivity. An attempt to determine source of outflowing water by conductivity measurements only could give equivocal results. One should have in 10 mind examples of concentration of chloride and sodium ions in water from sea spray deposits in snow activated by its melt at the beginning of ablation season (Krawczyk and Wach, 1993).

Radon produced by radium decay in sediments and bed rocks enters subglacial waters and can be added to the isotopic signature of waters leaving glacier system. 15 Examination of the isotopic composition of meltwaters is an important tool for judging of fate/history of meltwaters circulating in and under glaciers, including the accumulation season (Peter et al., 2006).

The Radiation Physics Laboratory, University of Luxembourg, was dealing with natural radioactivity, mainly radionuclides of the Uranium and Thorium Decay Series and notably radon. It had been involved in the developing of conceptual and numerical models to study the dispersion and transport of radionuclides in subsoil and groundwater environments (Kies et al., 2005). Good expertise has been gained in the metrology of radioisotopes, especially those of the natural decay chains (Tosheva et al., 2004). Radon as a tracer for understanding hydrological processes in combination with other parameters has been used in many studies, e.g to estimate the infiltration rate of surface waters to aquifers (Hoehn and von Gunten, 1989) or vice versa, i.e. to determine ground water discharge into surface waters (Burnett and Dulaiowa, 2006; Schmidt et al., 2009; Swarzenski et al., 2007). Radon is used to determine ground water flow

Overview on radon measurements in Arctic glacier waters

A. Kies et al.

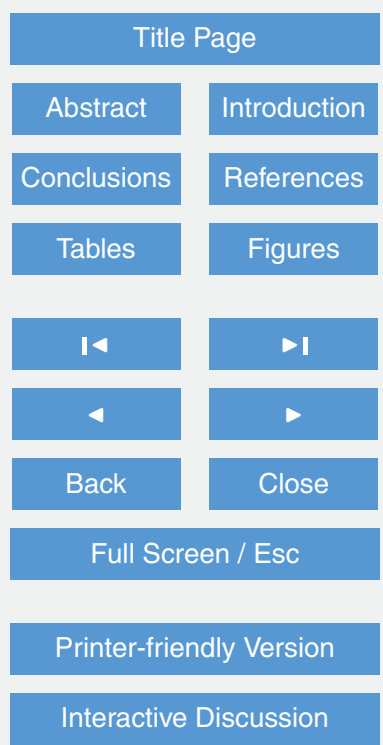


velocities (Kafri, 2001; Schubert and al., 2011). A motivation of the present study is to analyze if radon can be used in glaciology in a similar way.

A widely recognized technique to assess meltwater flowpaths and travel time consists in injecting artificial tracers and in monitoring their appearance at the glacier out5 lets. An alternative to artificial tracer consists in exploiting the information carried by the composition of ions taken up by the meltwaters, here we concentrate on the uptake of radioactive nuclides especially the noble gas radon.

For the study of radon it is preferable to rely on artesian outflows or important outflows routing water from a confined system to the glacier tongue with limited turbu10 lences. The reason is a possible degassing of radon before meltwater can be accessed. High transfer velocity and the great bulk water flow limit radon degassing, otherwise the unknown amount of degassed radon limit the significance of outcomes. Whenever radon is measured in meltwaters, a recent contact with sediments and bedrock can be deduced.

High radon concentrations document an intensive contact with sediments; to a lesser extend with rocks with a smaller exchange surface compared to sediments. This contact must have taken place not more than a few radon half lives (up to 20 days) before the measuring process.

\section{Radon (222 Rn) as investigation tool}

20 In hydrology, a classic isotopic hydrograph study during rain events leads to a quantitative portioning of runoff water into contributions from different waters: superficial runoff, interflow water and groundwater (Kraemer and Genereux, 1998; Kies et al., 2005). The aim of the present work is an attempt to use natural radionuclides and especially radon to study glacier meltwater in a similar way.

25 Here we expected to allocate meltwater to their routes of drainage: on surface of glaciers (supraglacial), within ice bodies (englacial) and in glacier sole-ice contact zone

Overview on radon

measurements in

Arctic glacier waters

A. Kies et al.

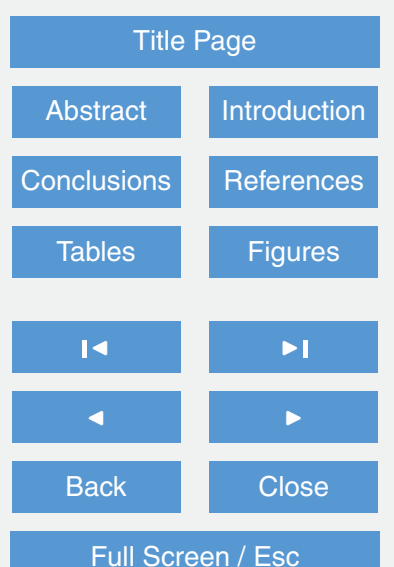

Full Screen / Esc

Printer-friendly Version

Interactive Discussion 
(subglacial), thus establishing a sort of hydrograph separation. This proposed attempt would be the first time for hydro-glaciological purposes.

Radon $\left({ }^{222} \mathrm{Rn}\right)$ is a radioactive noble gas (half-live $T=3.8$ days), it originates from the decay of radium $\left({ }^{226} \mathrm{Ra}\right)$, member of the natural ${ }^{238} \mathrm{U}$ series. After its creation, part of 5 the radon has the possibility to diffuse to the gaseous or liquid surroundings in contact with the hosting rocks and sediments. Soluble in water, radon can be carried by his carrier fluid over long distances during its mean life time of 5.5 days (period $T=3.8$ days). For water the radon concentration is commonly expressed in $\mathrm{BqL}^{-1}$ (Becquerel per Liter); in one liter of water, in the mean, one radon decay is observed every second. 10 The particle concentration of radon in water is always extremely small: a concentration of $20 \mathrm{BqL}^{-1}$, a typical value measured during the accumulation period at outflows of the target glacier, means that in average in one liter of water 20 radon atoms decay per second: 20 atoms out of 9.5 million radon atoms - among $3.3 \times 10^{19}$ millions of water molecules!

15 Radon is created from radium. For the radon atom to be mobilized, the radium atom has to be located on or very close to the boundary of the sediment grain or rock surface, such that the recoil energy during the alpha decay of radium allows the chemically inert radon atom to leave the host lattice. The decay process is not influenced by any chemical reaction. Radon concentrations in water depend on the radium concentrations in the rocks (as the member of the Uranium decay series). Very important factors are also the rock/sediment-water contact surface related to the sediment's grain sizes and the contact duration. Therefore meltwater containing radon gives secure information that part of this water has been recently in contact with sediments and the bedrock. The more radon the higher is the fraction of meltwater coming from the subglacial drainage system, the fraction without such contact being radon free.

Glacial meltwaters acquire solute in a manner that reflects the characteristics of the flow route taken. Factors including transit time, access to atmospheric gases and contact with reactive rock flour are important controls on the rate and magnitude of solute acquisition (Tranter et al.,1997). The solute content of bulk meltwaters should therefore

Overview on radon

measurements in

Arctic glacier waters

A. Kies et al.

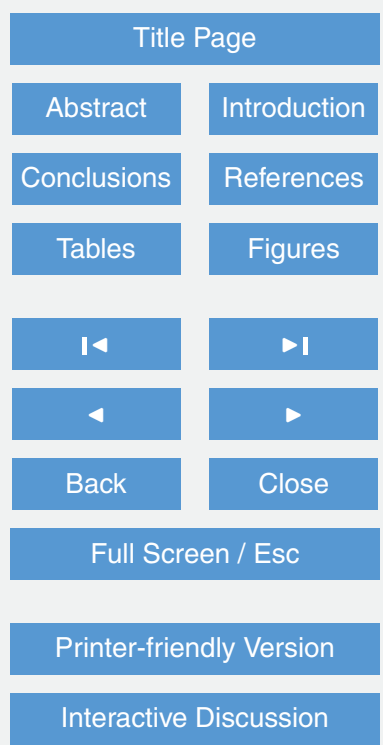


provide a composite picture of the flow contribution of different hydrological reservoirs, so that glaciers with different hydrological systems and bedrock geologies produce contrasting bulk meltwaters. Different ionic species are acquired by contact during water flow through the glacier drainage system; such contact is achieved most effectively at 5 the glacier bed. In meltwater, temporal variations of ionic concentration (Gordon and al.,1997; Peter et al., 2006) and radon may be interpreted in terms of the water flow pathways. High conductivity, high ionic stable and radioactive element concentrations indicate contact with reactive sediments and rocks, possibly for extended periods of time. Furthermore, high radon concentrations, besides the indication of intensive water 10 contact with sediments/rocks, inform in addition that this contact happened less than some 20 days before his measurement. In the case of radon a steady equilibrium concentration can be expected whenever uptake of radon is counterbalanced by decay.

Data with regard to flow paths suggest, that excess water that cannot be drained through sediment as groundwater or, that flows over relatively impermeable bedrock, moves fast through tunnels that may be cut into the bed (Nye N channels) or excavated up into the ice (Rothlisberger $R$ channels) (Eyles, 2006). This water is not able to take up radon in appreciable concentrations due to short distance or short time of contact with rock substrate.

Roughly one can distinguish between two subglacial flow systems: canalized and 20 distributed (Brown, 2002; Swift et al., 2002), (Fig. 1).

The canalized flow system has concentrated inputs of meltwater via moulins or crevasses, it has large water fluxes, often strongly turbulent with high velocities and it covers a small proportion of the glacier bed. As this system has low possibility to uptake radon, its concentrations are very low or absent. However, if confined, this system is likely to transport radon to the outflow when mixed sub glacially with radon bearing water. Low transport times minimize the lost of radon due to decay during transport.

The distributed subglacial drainage system (usually in the form of a linked cavity pattern) has low flow velocities with sheet, cavity or porous flow at the ice-bed interface. Resistive or restricted flowpaths cover a large proportion of the glacier bed through

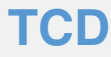

9, 2013-2052, 2015

Overview on radon measurements in Arctic glacier waters

A. Kies et al.

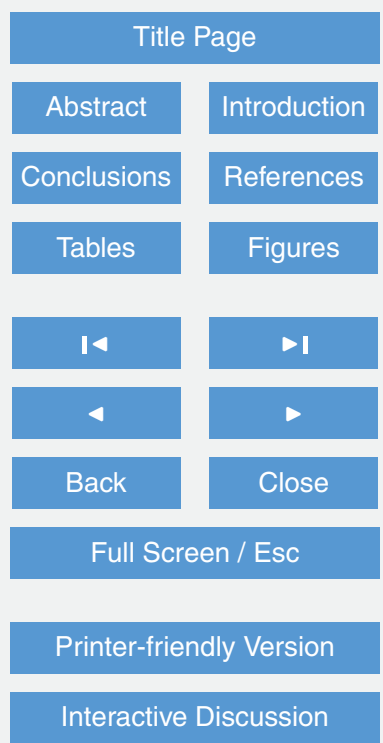

Interactive Discussion 
a network of shallow canals over areas of basal sediment. Direct surface meltwater inputs are absent or scarce; most meltwater derives from long retention cycle or basal melting. The distributed system predominates where glacier overburden pressure or ice flow prevents rationalization into a channelized network and in overdeepenings 5 (Swift et al., 2002); besides it is the form of drainage during winter without any supply of superficial meltwater. The distributed drainage system is the predominant source of radon, with an important restriction: the contribution to the outflow must not be longer than several radon decay periods. An indirect way to track the contribution of melwater at the outflow originating from the distributed system are increased ionic concentrations 10 and transported fine grained sediments with Lead-210, the long living decay product of radon with 22.4 years half-life.

Meltwaters from glaciers drained by well-developed tunnels are radon free or have very low radon concentrations. Cold glaciers have no distributed system and meltwaters contain no radon. Increased radon levels in meltwater are a direct proof that at 15 least part of the glacier has a polythermal regime.

\section{Methods}

For the radon measuring process, water was sampled in $120 \mathrm{~mL}$ radon tight bottles; they were carried, in winter in thermo bags, to the environmental laboratory of the Hornsund Polish Polar Station (HPPS). Here they were analyzed by the liquid scintillation technique: $12 \mathrm{~mL}$ of sample water were replaced by $10 \mathrm{~mL}$ of scintillator; vigorous shaking for $2 \mathrm{~min}$ allowed most of radon to move from the water into the scintillator. After waiting for water-scintillator phase separation, $7 \mathrm{~mL}$ of scintillator were filled into a vial. A waiting time of more than $3 \mathrm{~h}$ allowed reaching equilibrium between radon and its short lived decay products. Decay of radon between sampling and measurement was taken into account. Measurements were performed in a portable Liquid Scintillation Counter (Triathler, Hidex) allowing alpha-beta separation. The limit of detection of this procedure is $0.1 \mathrm{BqL}^{-1}$. This methodology was adapted for the purpose of this study
TCD

9, 2013-2052, 2015

Overview on radon

measurements in

Arctic glacier waters

A. Kies et al.

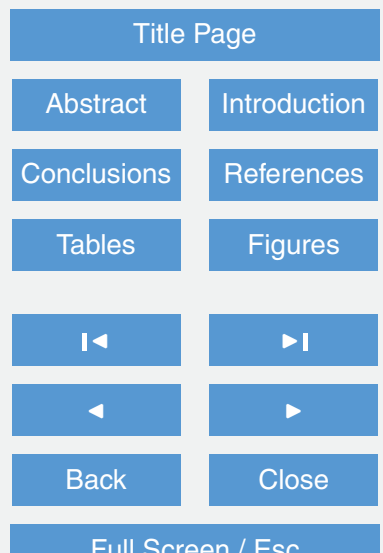

Full Screen / Esc

Printer-friendly Version

Interactive Discussion 
from routine set-up in the laboratory (Tosheva et al., 2009); it was calibrated based on water with known radon content.

Each sampling was combined with an in-situ measurement of electric conductivity and temperature with a RBR C-T probe described below. In the chemical laboratory 5 of Hornsund PPS, electric conductivity and $\mathrm{pH}$ were obtained by a Hanna HI 9828 multiparameter equipment. For chosen samples the concentrations of main ions were recorded by High Pressure Liquid Chromatography (HPLC) in the environmental laboratory of HPPS. In the radiochemical laboratory at the University of Luxembourg the concentrations of relevant natural radionuclides were measured for a limited number 10 of samples after radiochemical treatment, either by alpha spectroscopy or by liquid scintillation (Tosheva et al., 2009).

Besides point measurements, continuous recordings of radon were performed in August-September 2008, 2009, 2010 and 2011 at an important artesian outflow of Werenskioldbreen. To measure radon continuously in the water phase a silicon diffu15 sion tube, connected to a radon-in-air monitor, was put into flowing water. Diffusion of radon atoms through the silicon wall occurred until the equilibrium partition was obtained. We used the partition coefficient of radon between water and air. This coefficient depends on temperature; for meltwater around $0{ }^{\circ} \mathrm{C} K_{\text {water/air }}$ it is close to 0.1 (Clever, 1979). Every 20 or $30 \mathrm{~min}$ the air in the silicon tube was pumped for minutes through a closed circuit of radon tight tubes into a scintillation cell where radon and radon progeny decays were counted. The measuring unit allowed also for the determination of the total dissolved gas pressure (TDGP), based on thin walled silicon tubing and a differential pressure meter. TDGP is a parameter easy to measure continuously; devices are available from fishing industries where the survey of total dissolved gas pressure is crucial for the fish survival. The electrical power was supplied by a 50 Watt solar panel.

Since 2006, our first visit to Werenskioldbreen, combined continuously recording conductivity-temperature RBR $X R-420^{T M}$ probes $(C-T)$ were installed, close to or directly into the artesian outflow; at location W1 (Fig. 2) for longer periods. The tem-

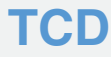

9, 2013-2052, 2015

Overview on radon

measurements in

Arctic glacier waters

A. Kies et al.

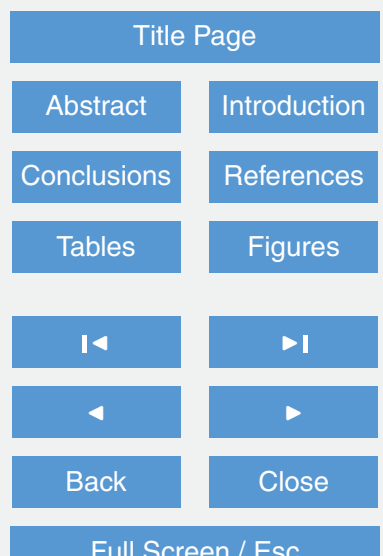

Full Screen / Esc

Printer-friendly Version

Interactive Discussion 
perature probe was a 24-bit Thermometrics ${ }^{\mathrm{TM}}$ thermistor in a sealed unit together with the conductivity probe. It had a resolution of $10^{-5}{ }^{\circ} \mathrm{C}$, a range of $-5^{\circ} \mathrm{C}$ to $25^{\circ} \mathrm{C}$ and an accuracy of $\pm 0.002{ }^{\circ} \mathrm{C}$, IST-90, guarantied by the manufacturer. This high accuracy is essential for the study of meltwater where small changes can give hints on mixing

5 rations from meltwaters of different origins. The conductivity probe had a resolution of $0.01 \mu \mathrm{Scm}^{-1}$, a range of $0-2 \mathrm{mS} \mathrm{cm}^{-1}$ and an accuracy of $\pm 3 \mu \mathrm{Scm}^{-1}$. As the temperature of glacier meltwater is always close to $0^{\circ} \mathrm{C}$ it was chosen to measure the effective electrical conductivities.

The atmospheric conditions at the terminus and on different locations of the glacier 10 were obtained from meteorological stations operated by colleagues from the University of Wroclaw and the Institute of Geophysics Polish Academy of Sciences, Warsaw. We relied also on data from a TinyTag temperature logger installed in the forefield at some $300 \mathrm{~m}$ from the studied outflow.

As a rule, each water sampling for radon was combined with an in-situ recording with the C-T probe for some minutes, even during winter. Sometimes in April it was possible to monitor C,T continuously in outflows over days before they were frozen; this information could than be combined with point measurements of radon. In winter no continuous radon measurements were attempted.

\section{Field site}

20 For our investigation we chose the well studied Werenskiold Glacier $\left(77^{\circ} 04^{\prime} \mathrm{N} 15^{\circ} 22^{\prime} \mathrm{E}\right)$ situated in the south-western part of Wedel-Jarlsberg Land in SW Spitsbergen (Fig. 2). Some other glaciers in its neighborhood were sampled for comparison. Closeness of Werenskioldbreen to the Hornsund Polish Polar Station has made this glaciated catchment well studied in terms of geology, geomorphology, glaciology, climatology and hydrology as well (Czerny et al., 1993; Jania et al., 2002; Pälli et al., 2002; BukowskaJania, 2007; Kabala and Zapart, 2009; Ignatiuk, 2012; Piechota et al., 2012).

Overview on radon measurements in Arctic glacier waters

A. Kies et al.

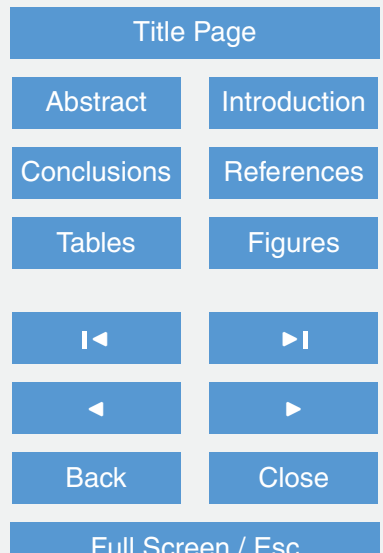

Full Screen / Esc

Printer-friendly Version

Interactive Discussion 
The Werenskiold Glacier basin is located at the meeting point of three tectonic blocks of the Hecla Hoek formation (Czerny et al., 1993). Petrographic composition of metamorphic series of the Hecla Hoek Formation is quite complicated there and varies around the glacier. An insight into petrological characteristics of sediments under5 neath of Werenskiold Glacier has been provided by Kowalska and Sroka (Kowalska and Sroka, 2008) by statistics of composition of pebbles in mouths of three subglacier tunnels in the middle, northern and southern lateral drainage systems (corresponding to $\mathrm{K} 1, \mathrm{~W} 2$ and $\mathrm{A}$ radon sampling locations - cf. Fig. 3). Pebbles represents rocks of quartz, quartz-feldspar or quartz-mica aggregates, quartzites and quartzose schists, - chlorite schists, mica schists, amphibolites, gneisses, marbles, marble and quartzite conglomerates in different proportions in particular locations. While gneisses dominate in the outflow of the southern Angel River, quartzites and quartzose schists, chlorite schists, marble and quartzite conglomerates with minor admixture of other rocks were noted in the central outflow and higher content of quartz, quartz-feldspar or quartz-mica 15 aggregates, quartzites and quartzose schist pebbles were identified in the northern Kvisla River outflow. Having in mind typical range of Uranium concentration in various rock types (Ivanovich, 1992), rock types from underneath Werenskiold Glacier have theoretically low to medium content of $U(0.5-6 \mathrm{ppm})$. Even if uranium/radium contents in rocks and sediments are low to medium, typically around $25 \mathrm{~Bq} \mathrm{~kg}^{-1}$, the radon concentrations measured in water can have the measured levels of $30 \mathrm{BqL}^{-1}$ if the water contact with sediments is intensive. Our experience on groundwater in Luxembourg showed that, despite low radium concentrations below $25 \mathrm{~Bq} \mathrm{~kg}^{-1}$ of the sandstone, the main local acquifer, the radon content in water is between 20 and $30 \mathrm{BqL}^{-1}$, similar to that in the Werenskiold meltwater (Tosheva et al., 2009).

Werenskioldbreen is a valley glacier with terminus on land, and have a $25 \mathrm{~km}^{2}$ area and a $235 \pm 15 \mathrm{~m}$ maximum thickness (Ignatiuk and al., 2014). Its polythermal structure with cold ice layer above temperate one (Fig. 1b) is quite well known thanks to radioecho soundings (Grabiec and al., 2010). The terminus and the lower part of the glacier are divided into two parts by the medial moraine; one third constitutes the northern
TCD

9, 2013-2052, 2015

Overview on radon

measurements in

Arctic glacier waters

A. Kies et al.

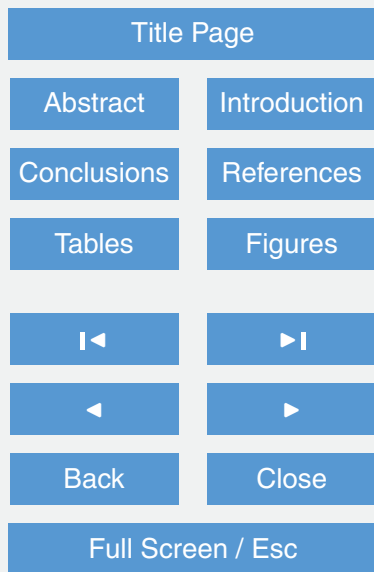

Printer-friendly Version

Interactive Discussion 
and two third the southern part (Fig. 2). The terminus and the lower part of the glacier are divided into two parts by a central moraine; one third constitutes the northern and two third the southern part (Fig. 3). Given the difference in height and the thickness of ice upglacier, the hydraulic head is considerable (Piechota et al., 2012). Thus, powerful 5 artesian-driven water spouts are common at the ice front during high melt or rain events in the ablation season. Englacial and subglacial conduit systems were observed and also partly explored by speleological techniques (Pulina, 1984; Pulina et al., 2003). During the ablation period subglacial channels are developed. The outflow springs at the front edge are supplied by a subglacial drainage system, possibly constituting 10 flow along bedrock or through a sediment layer. Cold basal ice at the terminus forces part of the outflow to follow older channels of subterranean routing preserved in the buried dead ice. The existence of spatially discrete flow paths conveying snow- and ice-melt to the terminus is the norm for polythermal-based glaciers on Svalbard (Wadham et al.,1998). Meltwater drainage from the Werenskiold Glacier was dominated by artesian outflows at the South and North ice margins. Recently glacier retreat led to a non artesian main outflow close to the northern lateral moraine, this outflow being the most important of Werenskioldbreen from 2010 to 2014.

Four areas at the terminus of Werenskiold were regularly sampled between September 2006 and September 2011 during yearly sampling campaigns: 2 areas in the northern part called K1 and K2; W1-W2 were important summer outflows to the South of the central moraine; $\mathrm{M}-\mathrm{A}$ is an area close to the southern end of the glacier front (Fig. 3). All areas were situated at the terminus of the glacier at an altitude around $70-80$ ma.s.l. The sampling dates covered the different periods of the glacial cycle: for the accumulation period three weeks measuring campaigns between beginning of April and beginning of May; in August-September for the ablation period.

In April part of the forefield was covered by ice at the mentioned locations. But only in $\mathrm{K} 1, \mathrm{~K} 2$ and sometimes in M-A running water or water outflows out of cracks on naled ice domes could be accessed in winter, often after braking an ice cover. Normally only samples from small artesian outflows or from running water were taken.

\section{TCD}

9, 2013-2052, 2015

Overview on radon

measurements in

Arctic glacier waters

A. Kies et al.

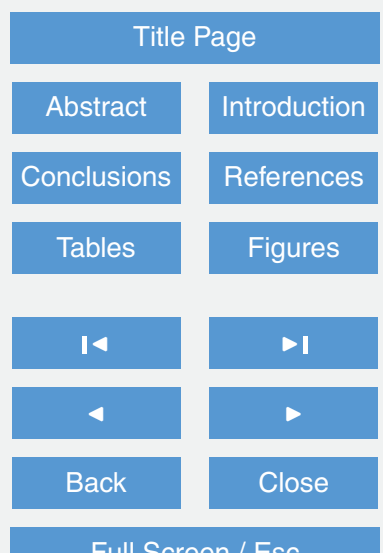

Full Screen / Esc

Printer-friendly Version

Interactive Discussion 
Often winter outflows were not active in the ablation season when the main outflows draining the glacier were reactivated. In the ablation period until 2010 only artesian upwelling water was sampled, thus a prior degassing of radon was avoided. As mentioned before, due to glacier retreat, the main artesian outflow at K1 changed to a non artesian one: this outflow is the most important of the glacier, the second in importance is located in $\mathrm{W}$; all other outflows sampled in the ablation period were superficial or inglacial meltwater flows, confirmed by low conductivity and close to zero radon levels.

\section{Results and discussions}

The first measurements of radon in glacier meltwater were performed September 2006 on two glaciers, one on a small cold glacier Ariebreen where radon levels were all very small or absent. On the Werenskiold Glacier, besides analyses of mainly superficial waters, it was possible to sample one important artesian outflow situated slightly southward from the central moraine. The results of this sampling were:

radon: $\quad 20 \pm 1 \mathrm{BqL}^{-1}$,

temperature: $0.030^{\circ} \mathrm{C}$,

el. conductivity: $77.0 \pm 0.3 \mu \mathrm{Scm}^{-1}$,

${ }^{238} \mathrm{U}: \quad 8.9 \pm 0.4 \mathrm{mBqL}^{-1}$

${ }^{234} \mathrm{U}: \quad 9.9 \pm 0.4 \mathrm{mBqL}^{-1}$,

${ }^{226} \mathrm{Ra}: \quad 7.6 \pm 0.7 \mathrm{mBqL}^{-1}$.

15 They encouraged us to continue in using radon as a tool to study glacier meltwater. Added are the results from the content of the main natural radionuclides. For the paper we will not comment on the radionuclides other than radon. From 2007 on, Werenskiold was visited regularly; whereas winter radon measurements rely only on scrap sampling, in late summer-autumn, besides scrap sampling, continuous measurements were performed on artesian outflows (Kies et al., 2011). In 2012 and 2013 no sampling
Overview on radon measurements in Arctic glacier waters

A. Kies et al.

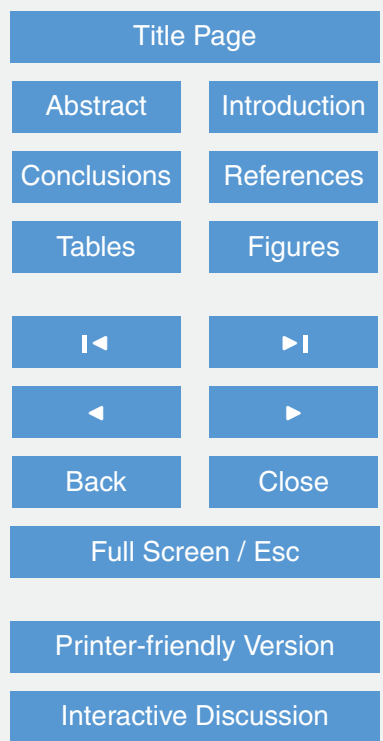

Interactive Discussion 
was performed. In 2014 other research obligations allowed only a short sampling visit to the glacier.

For the presentation and discussion of the results of the radon measurements we will focus in a first step on single measurements; continuous measurements will be 5 presented and discussed in a second step.

\subsection{Single measurement}

Besides radon measurements it showed that the most important co-parameters, easy to measure, were electrical conductivity and temperature. Tested was also a combination with total dissolved gas pressure.

10 Even one single radon measurement at a glacier outflow can give information, especially if paired with the mentioned parameters. Concerning electrical conductivity, in the following one has to be aware that there are fundamental differences in interpretation of the origin of electrical conductivity EC (proportional to the number of dissolved ions) and radon. Both signals are in relation with the duration and intensity of contact of water with sediments and rocks. Radon uptake is related to the existence and position of the radium atoms close to the grain surface, allowing the transfer by recoil of the newly created chemically inert radon atom into the pore space and further by diffusion into water in contact with pore space before carried away by flowing water, this independently of the local chemical conditions. This is in opposition to the uptake of ions, which depends on the local geochemical conditions, ex. reducing or oxidizing. Prolonged contact time increases the number of ions able to enter the liquid phase; the electric conductivity is rising. For radon this is also the case but there exists a limit concentration reached when the number of radon atoms entering the liquid phase is balanced by the number of decaying radon atoms. Radon does not allow information on water in contact with sediments/rocks that happened prior to 20 days, in opposition to electric conductivity, earlier uptake of ions leads at the outflow to a contribution to the electrical conductivity but no information by radon. As short time tracer radon reacts

Overview on radon measurements in Arctic glacier waters

A. Kies et al.

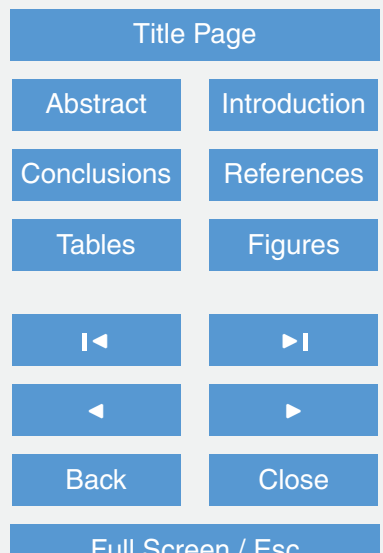

Full Screen / Esc

Printer-friendly Version

Interactive Discussion 
much more sensitively to a change in uptake and flow conditions compared to the other parameters.

In winter another important difference in radon-conductivity behavior was observed. Freezing of meltwater either in or under the glacier or even after the outflow leads to an 5 increase in the ion concentration in the unfrozen water as newly created ice is depleted in ions. This does not happen with radon whose levels are not influenced by the freezing process. Repeatedly it was possible to witness this behavior. In April in outflows that were in the process of freezing, very high electrical conductivities up to $2500 \mu \mathrm{Scm}^{-1}$ were recorded (expected were $330 \mu \mathrm{Scm}^{-1}$ ); whereas radon concentrations around $1028 \mathrm{BqL}^{-1}$ did not change.

In April sometimes it was possible to follow over several days radon concentrations and electrical conductivity EC for a given outflow $A$ on the tongue of the glacier. Freezing led often to a decrease and a complete stop of outflow $A$, whereas close by a new outflow $B$ became active. Before complete freezing the decreasing flow rate in A was always paired with a sharp increase in EC and ion concentrations, whereas the radon concentration did not change. In the newly created outflow $B$, radon and $E C$ were similar to outflow A before freezing. An example is given in Fig. 4 showing the increase of ionic concentration before refreezing. The refreezing had also an effect on isotopic composition, $\delta^{18} \mathrm{O}$ changed from $-11.5 \pm 0.1$ to $-12.3 \pm 0.1$ permil and $\delta^{2} \mathrm{H}$ from $-79.0 \pm 0.5$ to $-83.0 \pm 0.7$ permil.

With the glacier retreat each year a slightly different pattern was noticed on the lower slopes and in the forefield of the glacier. During the first years of our study, in the northern forefield a great number of frozen outflow "domes", some very impressive as over $2 \mathrm{~m}$ high, generally topped with important dry cracks. Sometimes it was possible to access here running water, often under pressure. This situation changed over the reported period, the ice-domes became more and more rare: now extensive ice sheets overlayed slightly moving water up to tenth $\mathrm{cm}$ depth. This water could be accessed after breaking the ice. Here increased electrical conductivities were measured, compared to water sampled from artesian outflows on the end-slope of the glacier.

Overview on radon measurements in Arctic glacier waters

A. Kies et al.

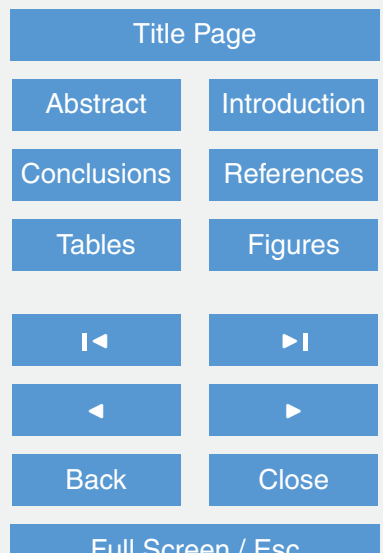

Full Screen / Esc

Printer-friendly Version

Interactive Discussion 
Concerning radon and electrical conductivity different scenarios were observed and for each scenario a distinct model can be proposed.

High radon and high conductivity: this is the result of intensive contact of meltwater with sediments and rocks before the outflow. It documents the existence of an active distributed system that contributes mainly or nearly exclusively to the outflow. This situation is typical for the accumulation period. Their values may be retained as representing the sole distributed system.

Table 1 shows the April mean radon levels at outflows at the location K2, North of the central moraine (Figs. 3 and 5).

10 Figure 5 documents the result of the April measurement campaign in location $\mathrm{K} 1$ and K2. It shows a quite different radon levels in the measured outflows.

Especially in 2010 in artesian outflows at K2 constant high radon concentrations were measured (Table 1 and Fig. 4). At the same time, at K1, close to the northern lateral moraine, running water could be sampled under the extended ice surface. Here the 15 conductivities were generally very high and the radon concentrations low, documenting a complete different situation discussed below.

Low radon and high electric conductivity: three different scenarios are possible:

- Sc-a, Radon escapes from the meltwater during turbulent flow prior to sampling.

- $S c-b$, radon decays before the outflow of water from an in-glacial reservoir;

- Sc-c, radon decays after leaving the glacier but before the meltwater is sampled.

$\mathrm{Sc}-\mathrm{a}$ is the case at glacier rivers. After the outflow from a temperate glacier with an active distributed system, radon degassing due to turbulent flow and mixing with radon free event water leads to low radon concentrations. But even rive water charged with small amount of radon gives valuable information. In August 2014 at the glacier river 25 outflows of two landbased polythermal glaciers Werenskioldbreen and Gäsbreen radon levels of $0.5 \pm 0.1 \mathrm{BqL}^{-1}$ confirmed that the glaciers are polythermal.

Scenario $S c-b$ was observed in April 2008 at the location K2 where usually high radon values are recorded. On top of an ice dome an important outflow of meltwater 2027

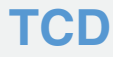

9, 2013-2052, 2015

Overview on radon

measurements in

Arctic glacier waters

A. Kies et al.

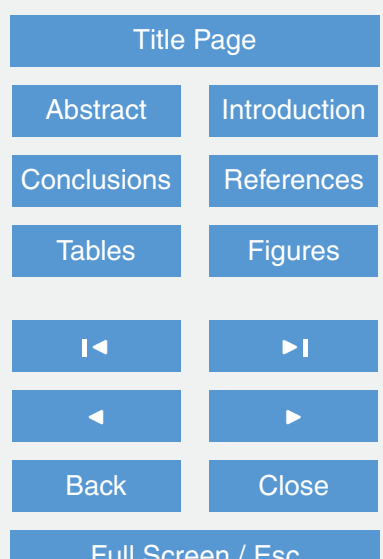

Full Screen / Esc

Printer-friendly Version

Interactive Discussion 
could be accessed. Stable weather conditions allowed, over a week, continuous monitoring of temperature and electrical conductivity. During this period, several visits to the forefield allowed water samples to be taken after removing newly formed ice above the RBR measuring device (like copping an egg). Radon concentrations were stable $51.0 \pm 0.1 \mathrm{BqL}^{-1}$ for two weeks; expected were levels above $25 \mathrm{BqL}^{-1}$. The electrical conductivity varied between 215 and $218 \mu \mathrm{Scm}^{-1}$, the outflow temperature was low compared to those recorded usually on April artesian outflows. The continuously high flow rate, under moderate pressure and high TDGP, suggested a direct glacier outflow. The proposed explanation is an outflow from a sub-glacial reservoir filled with water 10 from the distributed system (high conductivity) but allowing radon decay in the reservoir; a decay time of some 16 days can be guessed as the mean retention time in this subglacial reservoir.

Sc-c became more and more common for the April measuring campaigns in the northern $\mathrm{K}$ location of Werenskiold. As a consequence of glacier retreat, the fore15 field of Werenskiolbreen, situated between the northern lateral moraine and the middle moraine, underwent a dramatic change during 5 consecutive April investigation periods. In 2007 many, often imposing $2 \mathrm{~m}$ high ice domes of naled ice were observed, with cracks where sometimes flowing water, often under pressure, could be sampled. With receding glacier, fewer ice domes were observed from year to year coupled with an increasing amount of an important surface distribution of a not frozen shallow water body under an ice cover. The 2011 and 2014 visits in the ablation period to these locations gave an explanation to these observations. Due to the retreat of the glacier a former subglacial channel system appeared, active in mentioned winters, which explained the former presence of the ice domes.

25 In April 2011 visits during two weeks to the forefield of Werenskioldbreen showed no active direct outflow, water sampled in $\mathrm{K} 1$ and $\mathrm{K} 2$, under the ice cover had stable radon concentrations of around $3 \mathrm{BqL}^{-1}$. April measurements from previous years in $\mathrm{K} 2$, in outflows on the glacier tongue, showed a mean concentration of $30 \mathrm{BqL}^{-1}$. This value is taken as reference for the distributed system and for the inflow into the extended
TCD

9, 2013-2052, 2015

Overview on radon

measurements in

Arctic glacier waters

A. Kies et al.

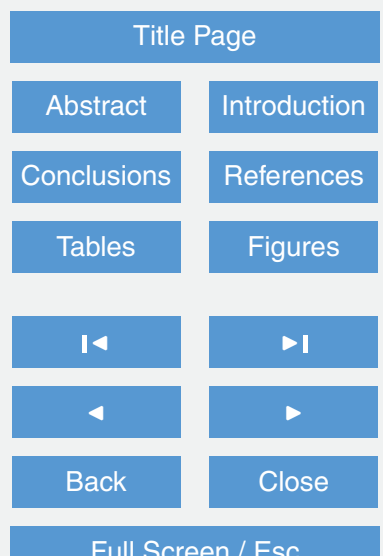

Full Screen / Esc

Printer-friendly Version

Interactive Discussion 
shallow water body. It is possible to guess a lifetime of 12 days between meltwater outflow of the glacier and before freezing or runoff, corresponding roughly to three radon periods of 3.8 days. The higher electric conductivity, $300 \mu \mathrm{S} \mathrm{cm}^{-1}$ compared to some $230 \mu \mathrm{S} \mathrm{cm}^{-1}$ from previous years, is the result of the freezing process mentioned 5 before.

Another illustration of scenario Sc-c is given by measurements in August 2014 on Gäsbreen opposite to HPPS over the Hornsund fjord. In August 2014, at the outflow close to the sea of this landbased glacier situated $3 \mathrm{~km}$ inland, $0.5 \pm 0.1 \mathrm{BqL}^{-1}$ were recorded. In the river halfway between the lake in front of the glacier and the sea 10 outflow these concentrations were $0.8 \pm 0.1 \mathrm{BqL}^{-1}$. Here the electric conductivity was $80 \mu \mathrm{Scm}^{-1}$, the temperature $3.23^{\circ} \mathrm{C}$. Interesting was the comparison of these values with an inflow into the lake $\left(0.6 \mathrm{BqL}^{-1}, 105 \mu \mathrm{Scm}^{-1}, 1.75^{\circ} \mathrm{C}\right)$. Based on the radon measurements we could conclude that Gäsbreen is at least for a part a temperate glacier, with a possible underground inflow into the lake in the forefield of the glacier. Later 15 investigations on 31 August 2014 showed an artesian outflow in front of the glacier charged with $8 \mathrm{BqL}^{-1}$ radon $\left(0.027^{\circ} \mathrm{C}, 25.7 \mu \mathrm{Scm}^{-1}\right)$. The data from Gäsbreen mentioned above, confirm our guess that this glacier is polythermal. As the radon concentration in the artesian outflow is high compared to conductivity, this allows guessing a recent intensive contact with sediments not long enough for the uptake of ions (conductivity) but enough for radon. As mentioned before the uptake is more effective for radon. As a tracer radon is more sensible than ionic concentration.

High radon and low electric conductivity: This could be a hint for high radium concentrations at the water-rock/sediment contact before the outflow thus allowing increased uptake of radon compared to the other ions. This possibility can be excluded for the studied glacier as no sediments with increased radium concentrations could be measured so far.

Low radon and low electric conductivity: Surface meltwater and/or rain water transferred directly over moulins and channels to the glacier snout with minimal interaction time with sediments, short transfer times in channels at the base of the glacier. The

TCD

9, 2013-2052, 2015

Overview on radon

measurements in

Arctic glacier waters

A. Kies et al.

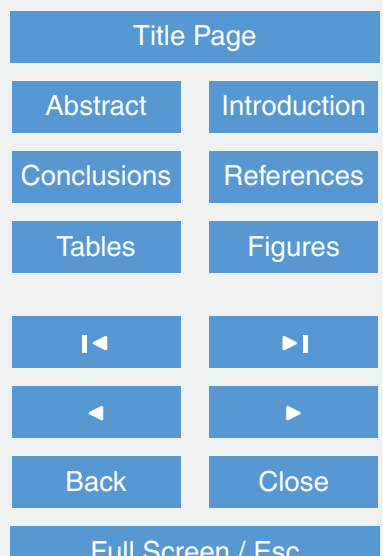

Full Screen / Esc

Printer-friendly Version

Interactive Discussion 
mentioned scenario is always the case for cold glaciers. It might be also a case of water conduits in the cold ice frontal zone of land based polythemal glaciers. Other studies, not discussed here, show the radon uptake in moraines after infiltration of radon free meltwaters.

Intermediate radon and intermediate electric conductivity: This situation is typical for the ablation period on main or artesian outflows at polythermal glaciers. It is the result of mixing of different waters charged differently with radon and ions. At Werenskioldbreen the conductivity measured at the outflows during the ablation period varied from 25 to $70 \mu \mathrm{Scm}^{-1}$ effective EC, compared to $230 \mu \mathrm{Scm}^{-1}$ for the accumulation 10 period. Despite very high runoff after a period with intensive rain, the radon concentration of $6.7 \mathrm{BqL}^{-1}$ were measured end of August 2011 at the main outflow at the northern snout of Werenskioldbreen; $\mathrm{EC}$ was $51 \mathrm{BqL}^{-1}$. Mixing of water from the distributed system with the low conductivity and low radon canalized icemelt-rain water explained the observed data. The radon and electric conductivity levels measured in

15 April will serve as reference values for the distributed system, as the only active in the accumulation period. As mentioned previously these reference values, checked over years, are $30 \mathrm{BqL}^{-1}$ for radon and $230 \mu \mathrm{Scm}^{-1}$ (effective $\mathrm{EC}$ at $0^{\circ} \mathrm{C}$ ) for $\mathrm{EC}$. In the ablation period, a simple two component mixing model of - low conductivity and radon free meltwater reaching the basement through moulins and - meltwater from the distributed system, gives a guess of mixing ratios. In 2011, in the main outflow the radon concentration was $6.7 \mathrm{BqL}^{-1}$ and the electrical conductivity $51 \mu \mathrm{Scm}^{-1}$, leading both to $22 \%$ of the outflow originating from the distributed system and $78 \%$ from direct transfer. Even if these calculations are based on an over simplified model, they show that a distributed, sediment-based subglacial drainage system operated beneath at least part of the glacier. Sometimes radon levels are out of balance with this simple mixing model. Higher radon levels indicate a very active distributed system prior to outflow, with interaction time long enough for radon to reach high concentrations but not long enough for important geochemical interaction. In this case the mixing ratio should be based on radon. As an example one can consider the results of continuous radon and

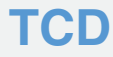

9, 2013-2052, 2015

Overview on radon

measurements in

Arctic glacier waters

A. Kies et al.

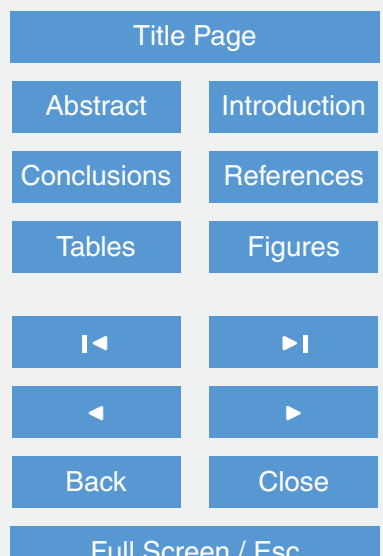

Full Screen / Esc

Printer-friendly Version

Interactive Discussion 
electrical conductivity measurements during a heavy rain event. Both radon levels and electric conductivity dropped, they were relatively more important for radon compared to electric conductivity. This will be discussed below.

On 27 August 2014, after 5 weeks without rain, at the main not artesian outflow at

5 the northern tongue of Werenskioldbreen (the same as mentioned before), the radon concentration was $9.7 \mathrm{BqL}^{-1}\left(0.026^{\circ} \mathrm{C}, 63.2 \mu \mathrm{Scm}^{-1}\right)$. On 2 September, after a rain event on 28 and 29 August and freezing in the upper glacier prior to sampling, radon concentration was $16.8 \mathrm{BqL}^{-1}$. Applying the simple mixing model leads to 32 and $56 \%$ contribution of the distributed system based on these two measurements. The higher 10 contribution of the distributive system compared to 2011 could be the unusual lack of rain events; the reason for the increase observed 2 September could be a kind of piston effect liberating meltwater from the distributed system. Again these measurements highlight the contribution to the discharge from basal melting.

These last measurements can explain the high radon concentrations of 20 Septem15 ber $2006\left(20 \mathrm{BqL}^{-1}\right)$, the sampling was done, after a day of light snowfall, under bright weather conditions and freezing in the upper glacier.

\section{Continuous radon measurements}

In late August-beginning of September 2008, 2009 and 2010 the continuous monitoring unit, described before, was installed in the artesian outflow W1 (Fig. 6). In 2011 the 20 flow rate of $\mathrm{W} 1$ had largely decreased as the meltwater was routed to a new artesian outflow that appeared closer to the receding glacier tongue. It was decided to monitor this new outflow. Besides radon and electric conductivity TDGP was measured continuously. Unfortunately we have no data on the flow rates of the studied outflows.

In late August-beginning of September 2008, 2009 and 2010 the continuous mon25 itoring unit, described before, was installed in the artesian outflow W1. In 2011 the flow rate of $\mathrm{W} 1$ had largely decreased as the meltwater was routed to a new artesian outflow that appeared closer to the receding glacier tongue. It was decided to shift the

Overview on radon

measurements in

Arctic glacier waters

A. Kies et al.

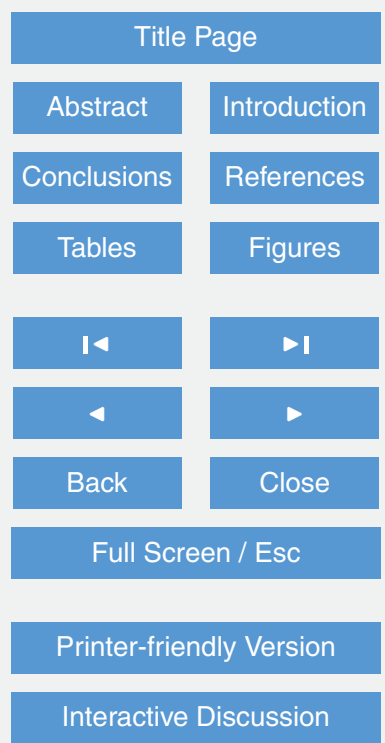


monitoring unit to this new outflow. Besides radon and electric conductivity TDGP was measured continuously. Unfortunately we have no data on the flow rates of the studied outflows.

In 2009 the radon concentrations at the artesian outflow W1 did not experience rapid 5 changes over time. Figure 7 shows results of the 2009 continuous measurements done with the set-up shown at Fig. 6. Clearly seen is the ice rim formed around the outflow, despite temperatures above the freezing point, giving a hint to hydraulic supercooling. According to different authors (Alley and al., 1998; Evenson et al., 1999; Tweed et al., 2005), hydraulic supercooling can be tracked if the following three conditions are satis10 fied: (1) water temperatures consistently below $0{ }^{\circ} \mathrm{C}$ despite ambient air temperatures well above freezing; (2) the formation of frazil ice crystals and flocs within the discharge and (3) the growth of anchor ice terraces around the vents. Furthermore Alley et al. (2003) proposed that overdeepenings, fundamental elements of glacial environments, are mainly the cause of glaciohydraulic supercooling.

From radar sounding the location of an overdeepening is well known, less than $1.5 \mathrm{~km}$ from the W1 (see Fig. 1). The existence of the observed supercooling phenomenon is a hint that the channel between the overdeepening and the frontal outflow followed the "normal" slope of the bed, was well developed and confined, allowing a rapid transfer and not intensive thermal interaction with ice or rocks. Thus loss of radon by degassing probably was low because of a short transfer time and limited degassing during transfer from the overdeepening to the artesian vent.

Both radon and EC raised continuously from 7 to 12 September; this increase was expected at the end of the ablation period as decreasing solar irradiation lowers the thawing and the direct inflow over moulins. A rain event on 12 September let to lower to recover after one day whereas radon continued to decrease and stayed low over the last days of observation. Before the event radon and conductivity evolved similarly, but were decupled after. The mixing ratio, constant before the event, was modified after the event when radon was constant over two days before rising. The slow variations of

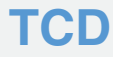

9, 2013-2052, 2015

Overview on radon

measurements in

Arctic glacier waters

A. Kies et al.

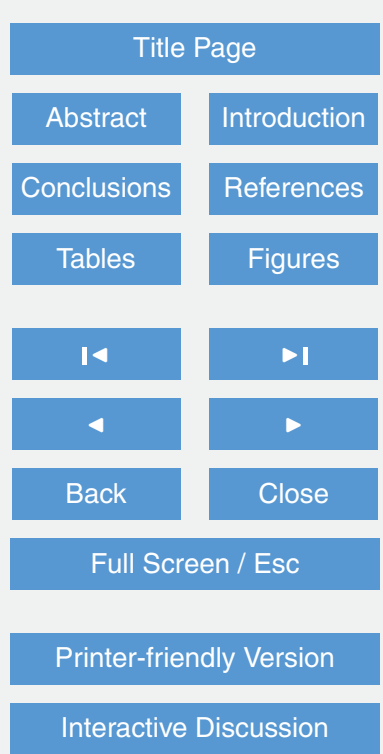


radon and EC confirm that this water was subglacially routed through non-temperate ice from an overdeepening system (cf. Fig. 1). The overdeepening region having a kind of a buffer function leveling out daily as well as abrupt variations in radon and EC. Radon concentrations were fairly low; the reason is a decay of radon before the outflow.

5 This may be related to the retention in the overdeepening, a retention time of a few radon periods ( $\sim 10$ days) can be supposed. This could also explain why EC recovers more quickly than radon after a inflow of event water into the overdeepenig system, taking into account the decay of radon.

In 2010 the recording of radon could be done over a long time period. That year 10 no ice rim was observed. Unfortunately the EC-T logger was not removed in time before freezing and was lost with the meltwater temperature and conductivity data. Even without the conductivity measurements an interesting pattern in relation to the other parameters could be retained. In 2010 the radon values were low compared to main outflow of the glacier; they were similar to those in 2008 and 2009. Radon levels showed 15 important variations as documented on Fig. 8, a quite different behavior compared to 2009.

Over the observation period, radon concentrations stayed low with a maximum of $2.8 \mathrm{BqL}^{-1}$. Radon concentrations experienced important variations with time whereas more stable radon concentrations were expected. Expected was also an increase of radon to the end of the ablation period as less event meltwater water due to heat input mixes with the meltwater from the distributive system. For the studied outflow this was not the case. An explanation is that the outflow active over the observation period carries water that is a mixture of water from the overdeepening with a steady concentration of guessed $2.8 \mathrm{BqL}^{-1}$ and event water with negligible radon levels. The lower the measured concentrations the higher is the relative amount of direct meltwater. This is the reason why in 2010 no supercooling was observed due to this inflow of event water before the outflow.

The continuous observations of temperature and rain (Fig. 8) show that both are responsible for the changing radon concentrations as event water originates either from

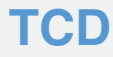

9, 2013-2052, 2015

Overview on radon

measurements in

Arctic glacier waters

A. Kies et al.

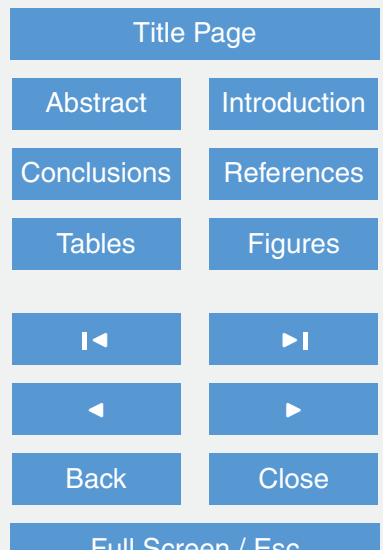

Full Screen / Esc

Printer-friendly Version

Interactive Discussion 
rain or melting due to heat input; an example is the rapid radon decrease after hot sunny days, here 12-14 September, days without rain. Whereas the influence of rain on radon levels at the outflow is immediate, the influence of increased heat input is delayed in time in the order of one day. Even if solar irradiance was not measured at the glacier, 5 the charging voltage of the battery by the solar panels gives fairly good information on the energy input to the glacier.

To the end of the observation period, mean radon concentrations decrease. This could be a hint of decreasing outflow from the overdeepening and an increased influence of event water. To the end of the year the outflow froze; visits to the site in 10 April 2011 could not show any presence of liquid water. After 2010 no more any hint of supercooling was observed.

In autumn 2011 the outflow W1 existed but the flow was much reduced compared to the previous years; the water being routed to the new outflow W2, also in the dead ice zone but closer to the glacier. In the following years this newly formed outflow W2 15 disappeared and the $\mathrm{W} 1$ outflow was reactivated. In 2014 radon was $3.0 \mathrm{~Bq} \mathrm{I}^{-1}\left(0.02{ }^{\circ} \mathrm{C}\right.$, $42.2 \mathrm{\mu Scm}^{-1}$ ) on 27 August, $5.3 \mathrm{BqL}^{-1}$ on 2 September. Interestingly this increase of a factor 1.7 is the same for the main outflow (see before), sampled at the same dates.

There exists an excellent correlation of radon and total dissolved gas pressure (Fig. 8). The mean high value of TDGP is a Supplement hint of the deep origin under increased pressure of the outflowing water, increased pressure inducing higher amount of dissolved gases. Event water was characterized by lower TDGP.

Unfortunately we missed the information on the continuous outflow rate. This would be a very useful parameter; we recommend that in a future similar study this parameter has to be included. We had information on the outflow rate of the river draining the glacier and its forefield. But as the contribution of the studied vent is small, we did not include these data in the discussion.

In 2011 , on the newly formed artesian outflow, south of the medial moraine, the continuous device for radon was installed. Radon and electric conductivity had a rapid and strong reaction to each increase in glacier ablation during strong winds and rain events.
TCD

9, 2013-2052, 2015

Overview on radon

measurements in

Arctic glacier waters

A. Kies et al.

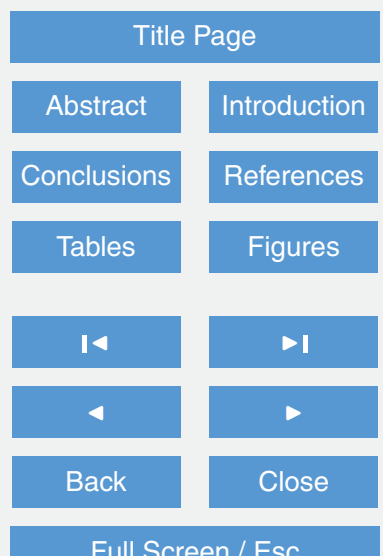

Full Screen / Esc

Printer-friendly Version

Interactive Discussion 
This is documented by the continuous measurement of radon and EC in September 2011, performed during an extreme rain-wind event in the mentioned artesian outflow of southern Werenskiold (Fig. 9).

Unfortunately the unexpected huge increase in the artesian outflow destroyed the 5 radon uptake system, but before destruction a drop in the radon levels by a factor of 10 could be documented (Fig. 9). The relative change in electric conductivity by a factor of 2 was lower compared to radon. Observed was also a difference in the reaction of $\mathrm{EC}$ and radon. At the beginning of the event, whereas EC is already decreasing radon rises slightly. An explanation could be at the beginning of the rain event a sort of piston 10 effect freeing water from the distributed system. The electric conductivity, after reaching a minimum value recovers whereas radon continues to decrease. This situation has been already observed in 2009. The pressure increase in the upper glacier routes stored inglacial meltwater to the outflow, this water has increased EC but low radon levels due to the radioactive decay of radon. At the outflow with diminishing contribu15 tion of direct event water the conductivity rises whereas radon concentration stays low before rising slowly. The drop in radon concentrations is generally more rapid than the recovering after a major ablation-rain event.

Figure 9 shows also an increase of water temperature due to the inflow of event water that has a slightly higher temperature and carries lower amount of ions and no radon. At the outflow the result is a mixture from different contributions, at the minimum the outflow was mainly event water. A good anti-correlation between temperature and conductivity is the result of the mixing of the different contributions.

In the following we report on radon investigations, which were done on other glaciers than Werenskioldbreen. In April 2007, 2008 and 2009, at the end of the accumulation period, outflows were sampled in the forefields of the land-based Nannbreen and of the southern land-based edge of Austre Torellbreen, glaciers located close to Werenskioldbreen. Figure 1 gives an overview of radon and EC measurements together with chemistry data. Radon concentrations were between 5 and $12 \mathrm{BqL}^{-1}$. Especially in the forefield of Torellbreen an important extend of water was accessible under an ice

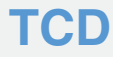

9, 2013-2052, 2015

Overview on radon

measurements in

Arctic glacier waters

A. Kies et al.

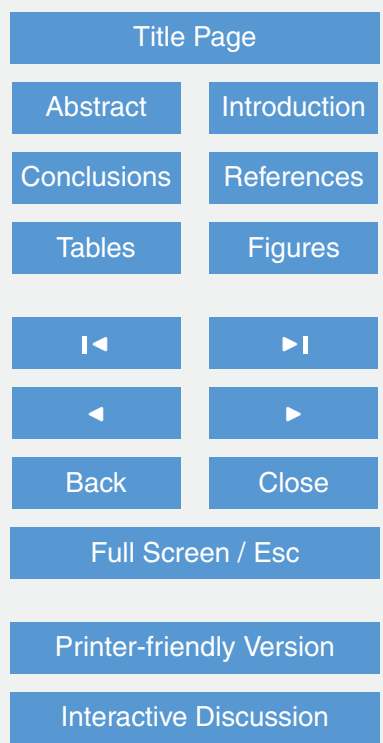


cover showing extremely high ionic concentrations; ions expelled during the freezing process increased the ion concentration in the non-frozen meltwater. Both indicators suggest long-term circulation of summer meltwaters originated in the upper part of the glacier (accumulation area) through percolation via firn layer to the glacier sole and 5 its cumulating at the bed followed by slow migration by a dispersed drainage system towards termini during winter. Low air temperatures in this period of the year cause formation of naled ice (icing) near the outflow locations on the land (Bukowska-Jania, 2007). Released water is flowing under and within such ice layers sometimes to a distance of dozens of meters. Mentioned supplementary studies at fronts of S Spitsbergen 10 glaciers are showing that water released during winter had contact with bed sediments, so drainage is of subglacial dispersed type. Differences in radon contents in particular outflows and glaciers have to be explained by further research.

Further applications of radon could be the determination of the amount of meltwater flowing directly into the sea from tidewater glaciers. Radon concentrations measured in front of glaciers could lead, after modeling of the mixing with sea-water, to the determination the amount of underwater glacier outflow. Similar techniques have been used to evaluate the underground inflow of water to the sea, not connected to glaciers (Burnett and Dulaiova, 2006). Water samples taken by one of us in front of Paierbreen (Horsund fjord) were slightly charged with radon, in opposition to sea water sampled close to a superficial water inflow from the same glacier where no radon decays could be seen.

\section{Conclusions}

For the first time repetitive radon measurements in waters outflows of Arctic glaciers, including winter and summer periods, were done. They show that radon is a useful 25 tool to gather information on the type of drainage systems of polythermal glaciers. Information could be gathered on the specifically subglacial component of discharge

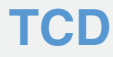

9, 2013-2052, 2015

Overview on radon measurements in Arctic glacier waters

A. Kies et al.

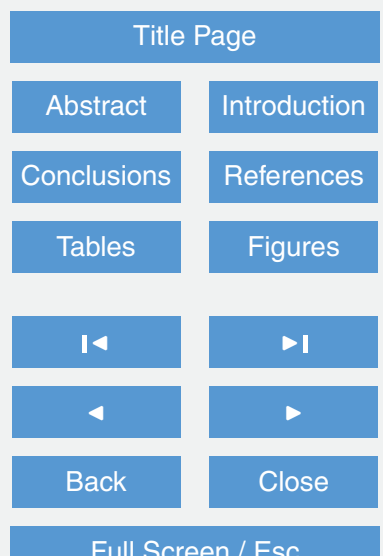

Full Screen / Esc

Printer-friendly Version

Interactive Discussion 
during the ablation period, gave information on the portion of water having contact with bed sediments and bedrock.

Radon is the only radioactive isotope allowing continuous measurements; in combination with continuous measurements of classical parameters like temperature $(T)$ 5 electric conductivity (EC) - total dissolved gas pressure (TDGP), it allows new insights when interpreting and modeling these data.

Most measurements were performed in outflows of the polythermal Arctic Werenskiold Glacier. However, Radon was documented in waters of several glaciers in Southern Spitsbergen.

10 The maximum Radon levels of ca. $30 \mathrm{BqL}^{-1}$ were measured in artesian outflows from the glacier snout during accumulation period in April. Such highest Radon concentrations can be taken as representative value for the distributed subglacier drainage system. Water from percolation through accumulation zone and its slow migration along the glacier bed allows longer contact with bedrock and bed sediments to enrich it by 15 Radon content. Development of channelized basal drainage in winter couldn't be expected due to lack of melt water supply from glacier surface. Heavy enough winter rainfalls are extremely rare to affect change of type of drainage system. Also, in April, the extensive water body in the forefield, supplied by an inaccessible outflow, could be dated.

20 In the ablation period, at the main outflow, it was possible to distinguish between canalised and dispersed systems, to guess the contribution of surface melting - event water and water originating from the dispersed system.

In summer/autumn continuous radon measurements in combination with T, EC and TDGP could be done on an artesian outflow whose end part was in dead ice; the channel was well developed only in the active ablation period. Visual inspection (ice rim) and temperature measurements gave a hint of water originating from an overdeepening. The discussion of the measurements could be done on basis of this supposition; as a short time tracer, radon provided information on transfer time or retention time in a subglacial reservoir.

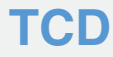

9, 2013-2052, 2015

Overview on radon measurements in Arctic glacier waters

A. Kies et al.

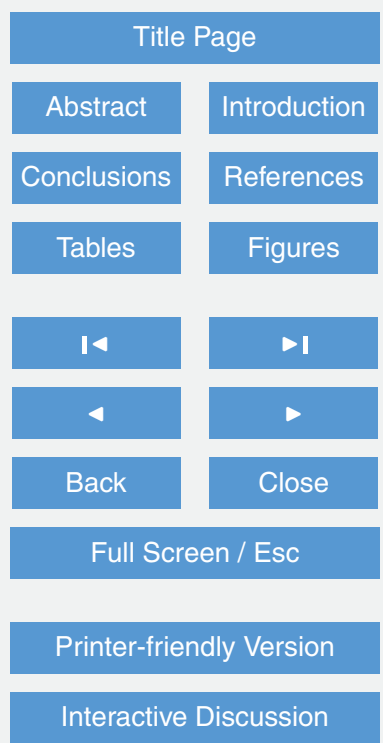

Interactive Discussion 
The use of Radon as a tracer seems to be new promising method of investigation. Radon is a natural tracer in opposition to artificial dye tracing, the last being impossible to apply in the winter period. A draw-back of tracing by radon could be degassing. This happens when water from a distributive system is conveyed by flow in R-Channels over 5 long distances. Another problem affecting radon levels at the outflow could be an underwater inflow of radon-charged groundwater. Radon should be measured in combination with other parameters. For interpretation of radon results information on outflow rate would be very useful, unfortunately we had not this information for the present study. Therefore, this direction of research has to be continued in a wider scope.

So far the radon measurements as described here can only be applied to polythermal land-based glaciers. The method could also be adapted to sea-based glaciers, here sampling and modelling would be more difficult, as underwater inflow will mix with seawater before sampling.

We still have to test this new method of identification of subglacial water component in glacier river discharge by use of additional data as geometry and pattern of subglacial channels from radio-echo sounding investigations. However the results presented here show that radon is an interesting innovative contribution to the study of Arctic glaciers drainage system with its spatial and temporal changes.

Acknowledgements. Thanks are due to the Institute of Geophysics Polish Academy of Sciences for the stays in the Hornsund Polish Polar Station and the logistic support; to the University of Luxembourg for mission funding. Part of glaciological field data were elaborated within the frame of the project "Arctic climate system study of ocean, sea ice and glaciers interactions in Svalbard area" - AWAKE2 (Pol-Nor/198675/17/2013) supported by the National Centre for Research and Development within the Polish-Norwegian Research Cooperation Programme.

Very warm thanks to Piotr Glowacki, and to friends and colleagues for assistance in the field.

Full Screen / Esc

Printer-friendly Version

Interactive Discussion

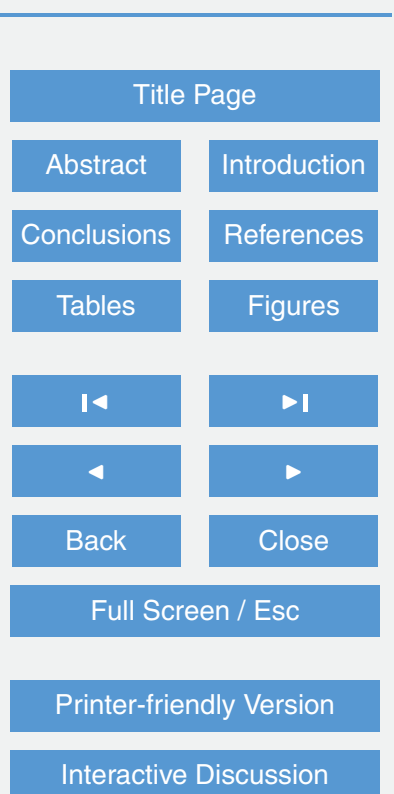

Overview on radon

measurements in

Arctic glacier waters

A. Kies et al.

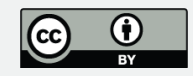




\section{References}

Alley, R. B., Lawson, D. E., Evenson, E. B., Strasser, J. C., Larson, G. J.: Glaciohydrologic supercooling: a freeze-on method to create stratified, debris-rich basal ice, II. Theory, J. Glaciol., 44, 563-569, 1998.

5 Boulton, G. S., Lunn, R., Vidstrand, P., Zatsepin, S.: Subglacial dainage by groundwaterchannel coupling, and the origin of esker systems: Part I - glaciological observations, Quaternary Sci. Rev., 26, 1067-1090, 2007.

Brown, H. G.: Glacier meltwater hydrochemistry, Appl. Geochem., 17, 855-883, 2002.

Bukowska-Jania, E.: The role of glacier system in migration of calcium carbonate on Svalbard,

10 Pol. Polar Res., 28, 137-155, 2007.

Burnett, W., C. and Dulaiova, H.: Radon as a tracer of submarine groundwater discharge into a boat basin in Donnalucata, Sicily, Cont. Shelf Res., 26, 862-873, 2006.

Clever, H., L.: Solubility Data Series, Krypton, Xenon and Radon - Gas Solubilities, Vol. 2, Pergamon Press, Oxford/UK, 1979.

15 Czerny, J., Kieres, A., Manecki, M., and Rajchel, J.: Geological Map of the SW part of WedelJarlsberg Land, Spitsbergen, $1: 25000$, Institute of Geology and Mineral Deposits, University of Mining and Metalurgy, Kraków, 61 pp., 1993.

Evenson, E. B., Lawson, D. E., Strasser, J. C. Larson, G. J., Alley, R. B., Ensminger, S. L., and Stevenson, W. E.: Field evidence for the recognition of glaciohydraulic supercooling, in: Glacial Processes Past and Present, edited by: Mickelson, D. M. and Attig, J. W., Geological Society of America Special Paper 337, 23-35, 1999.

Eyles, N.: The role of meltwater in glacial processes, Sediment. Geol., 190, 257-268, 2006.

Gordon, S., Tulley, M., and Lamb, H. R.: Variability in the chemical composition of in situ subglacial meltwaters, Hydrol. Process., 11, 59-77, 1997.

Grabiec, M., Jania, J., Clarke, G., Piechota, A., Budzik, T., Kolondra, L., Puczko, D., and Gajek, G.: Relation of changes of glacier geometry and thermal structure to drainage system development in Spitsbergen Glaciers, in: Arctic System in a Changing Earth, Second International Symposium on the Arctic Research ISAR-2, 2010, 56, 2010.

Hoehn, E., von Gunten, H. R.: Radon in groundwater: a tool to assess infiltration from surface waters to aquifers, Water Resour. Res., 25, 1795-1803, 1989.

Ignatiuk, D.: Bilans energetyczny powierzchni lodowca a zasilanie systemu drenażu glacjalnego Werenskioldbreen [The energy balance of the glacier surface and water supply of drainage

Overview on radon

measurements in

Arctic glacier waters

A. Kies et al.

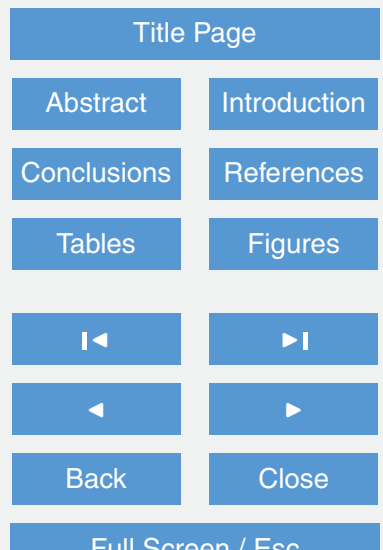

Full Screen / Esc

Printer-friendly Version

Interactive Discussion 
system of Werenskioldbreen], PhD Thesis, Faculty of Earth Sciences, University of Silesia, Sosnowiec, 2012.

Ignatiuk, D., Piechota, A., Ciepły, M., and Luks, B.: Changes of altitudinal zones of Werenskioldbreen and Hansbreen in period 1990-2008, Svalbard, AIP Conf. Proc., 1618, 275, 5 doi:10.1063/1.4897727, 2014.

Ivanovich, M. and Harmon, R. S. (Eds.): Uranium-Series Disequilibrium: Applications to Earth, Marine, and Environmental Sciences, 2. edn., Clarendon Press, Oxford, 910 pp., 1992.

Jania, J., Kolondra, L., and Aas, H. F. (ed.): Werenskioldbreen and surrounding areas. 17 Spitsbergen, Svalbard, Norway. Ortophotomap 1:25000, Katowice, Tromsø, Uniwersytet 18 10 Ślaski, Norsk Polarinstitutt, 2002.

Kabala, C. and Zapart, J.: Recent, relic and buried soils in the forefield of Werenskiold Glacier, SW Spitsbergen, Pol. Polar Res., 30, 161-178, 2009.

Kafri, U.: Radon in groundwater as a tracer to assess flow velocities: two test cases from Israel, Environ. Geol., 40, 392-398, 2001.

15 Kies, A., Hofmann, H., Tosheva, Z., Hoffmann, L., and Pfister, L.: Using ${ }^{222}$ Rn for hydrograph separation in a micro basin (Luxembourg), Ann. Geophys., 48, 101-108, 2005, http://www.ann-geophys.net/48/101/2005/.

Kies, A., Nawrot, A., Tosheva, Z., Jania, J.: Natural radioactive isotopes in glacier meltwater studies, Geochem. J., 45, 423-429, 2011.

20 Kowalska, A., Sroka, W.: Sedimentary environment of the Nottinghambukta delta, SW Spitsbergen, Pol. Polar Res., 29, 245-259, 2008.

Kraemer, T. F. and Genereux, D. P: Application of uranium- and thorium-series radionuclides in catchment hydrology studies, in: Isotope Tracers in Catchment Hydrology, edited by: Kendall, C. and McDonnell, J. J., Elsevier Science B. V., Amsterdam, 679-722, 1998.

Krawczyk, W. E., Wach, J.: Winter outflow of waters from the Werenskiold Glacier in the hydrological year 1985/1986, in: 20th Polar Symposium, Lublin, 1993, 403-411, 1993.

Pälli, A., Moore, J. C., Jania, J., Kolondra, L., Glowacki, P.: The drainage pattern of Hansbreen and Werenskioldbreen, two polythermal glaciers in Svalbard. The Changing Physical Environment, Sixth NY-Alesund International Seminar, 8-10 October 2002, 355-371, 2002.

30 Peter, M.W, Hodson, A., Heaton, T.: Chemical and isotopic switching within the subglacial environment of a High Arctic glacier, Biogeochemistry, 78, 173-193, 2006.

Piechota, A., Sitek, S., Ignatiuk, D., and Piotrowski, J. A.: Rekonstrukcja drenażu subglacjalnego Lodowca Werenskiolda (SW Spitsbergen) na podstawie modelowania numerycznego

Overview on radon

measurements in

Arctic glacier waters

A. Kies et al.

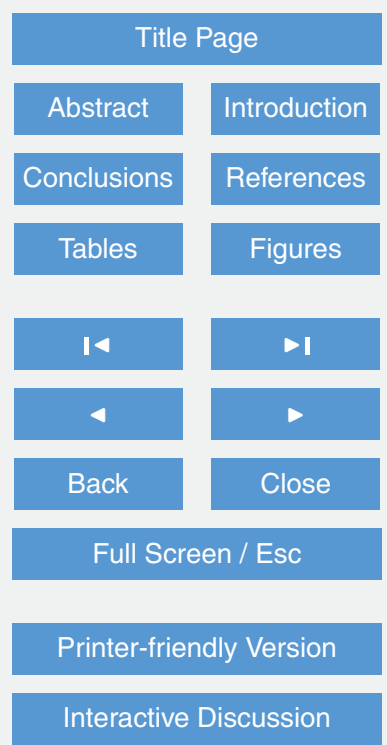


[Reconstructing subglacial drainage of Werenskiold Glacier (SW Spitsbergen) based on numerical modelling, B. Państwowego Inst. Geolog., 451, 191-202, 2012.

Pulina, M.: Glaciokarst phenomena in Spitsbergenm, Norsk Geogr. Tidsskr., 38, 163-168, 1984.

5 Pulina, M., Řehák, J., and Schroeder, J.: Les cavités glaciaires dous le regard spéléologique, Karstologia, 42, 23-36, 2003.

Raymond, C. F., Benedict, R. J., Harrison, W. D., Echekmeyer, K. A., and Sturn, M.: Hydrological discharges and motion of Fels and Black Rapids Glaciers, Alaska, USA: implications for the structure of their drainage systems, J. Glaciol., 41, 290-304, 1995.

10 Schmidt, A., Stringer, C. E., Haferkorn, U., and Schubert, M.: Quantification of groundwater discharge into lakes using radon-222 as naturally occurring tracer, Environ. Geol., 56, 855863, 2009.

Schubert, M., Brueggemann, L., Knoeller, K., and Schirmer, M.: Using radon as an environmental tracer for estimating groundwater flow velocities in single-well tests, Water Resour. Res., 47, W03512, doi:10.1029/2010WR009572, 2011.

Swarzenski, P. W., Reich, C., Kroeger, K. D., and Baskaran, M.: Ra and Rn isotopes as natural tracers of submarine groundwater discharge in Tampa Bay, Florida, Mar. Chem., 104, 69-84, 2007.

Swift, D. A., Nienow, P. W., Spedding, N., and Hoey, T. B.: Geomorphic implications of subglacial drainage configuration rates of basal sediment evacuation controlled by seasonal drainage system evolution, Sediment. Geol., 149, 5-19, 2002.

Tosheva, Z., Stoyanov, K., Nicholev, L., and Kies, A.: Comparison of different methods for uranium determination in water, J. Environ. Radioactiv., 72, 57-63, 2004.

Tosheva, Z., Hofmann, H., and Kies, A.: Spatial distribution investigation of radioactivity of potable waters in Luxembourg, J. Radioanal. Nucl. Ch., 282, 501-505, 2009.

Tranter, M., Sharp, M. J., Brown, G. H., Willis, I. C., Hubbard, B. P., Nielson, M. K., Smart, C. C., Gordon, S., Tulley, M., and Lamb, H. R.: Variability in the chemical composition of in situ subglacial meltwaters, Hydrol. Process., 11, 59-77, 1997.

Tweed, F. S., Roberts, M. J., and Russell, A. J.: Hydrologic monitoring of supercooled meltwater from Icelandic glaciers, Quaternary Sci. Rev., 24, 2308-2318, 2005.

Wadham, J. L., Tranter, M., and Dowdeswell, J. A.: The hydrochemistry of meltwaters draining a polythermal-based, high Arctic glacier, South Svalbard: I. The ablation season, Hydrol. Process., 12, 1825-1849, 1998.

Overview on radon

measurements in

Arctic glacier waters

A. Kies et al.

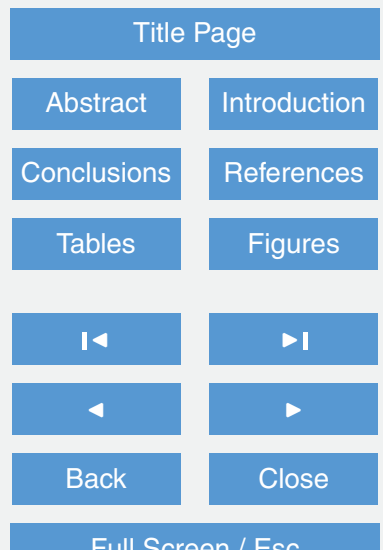

Full Screen / Esc

Printer-friendly Version

Interactive Discussion

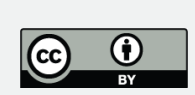


Table 1. Mean radon and el. conductivity levels measured during the end of accumulation period at one location on the lower slopes of Werenskioldbreen. A discussion of the data is in the text.
TCD

9, 2013-2052, 2015

Overview on radon measurements in

Arctic glacier waters

A. Kies et al.

\section{Title Page}

\begin{tabular}{lcc}
\hline $\begin{array}{l}\text { Location } \\
\mathrm{K} 2\end{array}$ & $\begin{array}{c}{ }^{222} \mathrm{Rn} \\
\mathrm{Bq} \mathrm{L}^{-1}\end{array}$ & $\begin{array}{c}\text { eff. el. cond. } \\
\mu \mathrm{S} \mathrm{cm}^{-1}\end{array}$ \\
\hline 2007 & $12-16.2$ & 235 \\
2008 & 1 & 215 \\
2009 & $24-29$ & 238 \\
2010 & $31-33$ & 230 \\
2011 & 3.5 & 300 \\
\hline
\end{tabular}

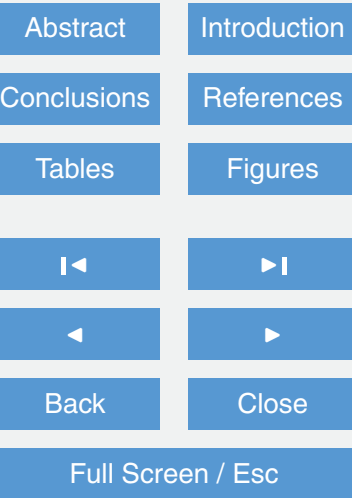

Printer-friendly Version

Interactive Discussion 

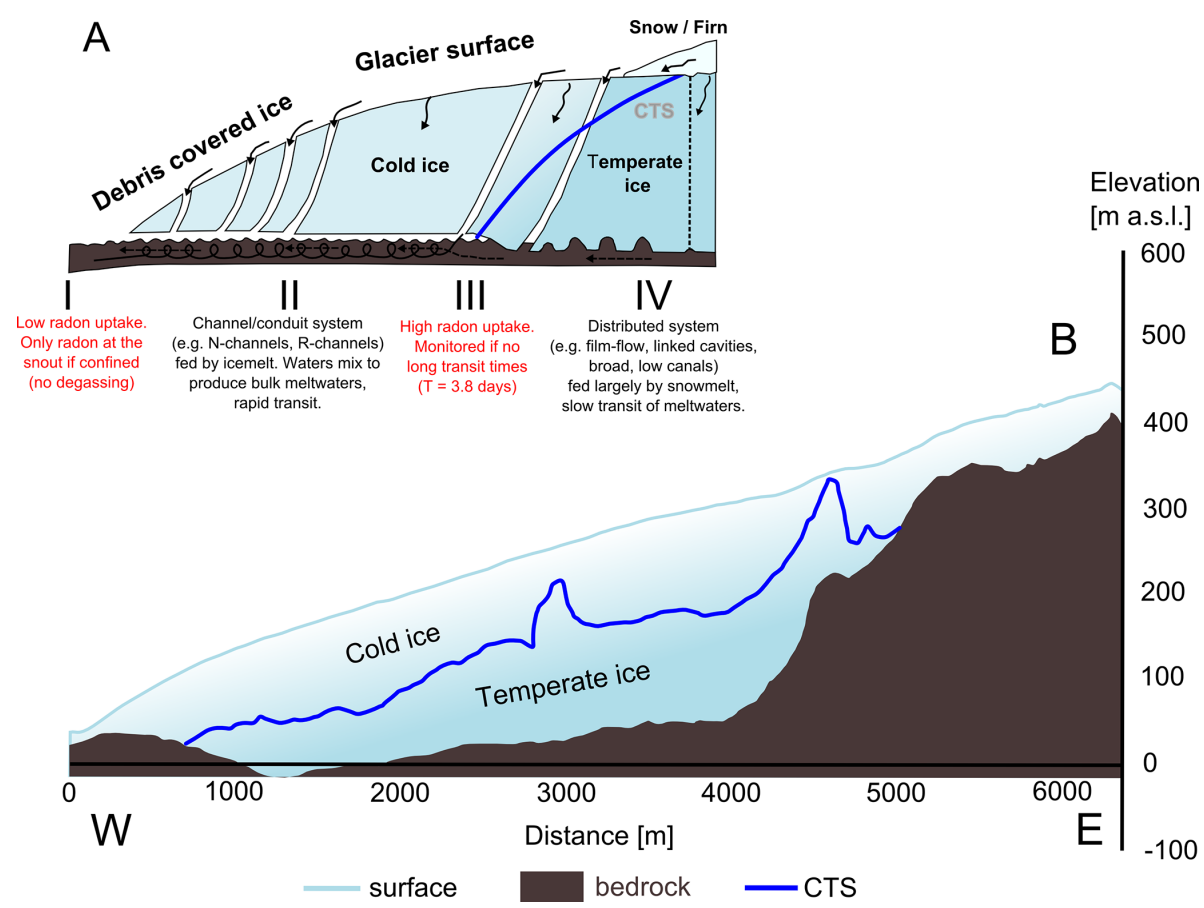

Figure 1. Glacier longitudinal profiles: (a) a conceptual scheme of glacier drainage systems (adapted from Brown, 2002) supplemented by radon uptake and transport; (b) Werenskioldbreen based upon radio-echo sounding data (courtesy of M. Grabiec et al., 2010 - modified): CTS - cold/temperate ice boundary surface (for location of the profile see Fig. 2).

\section{TCD}

\section{9, 2013-2052, 2015}

Overview on radon measurements in

\section{Arctic glacier waters}

A. Kies et al.

\section{Title Page}

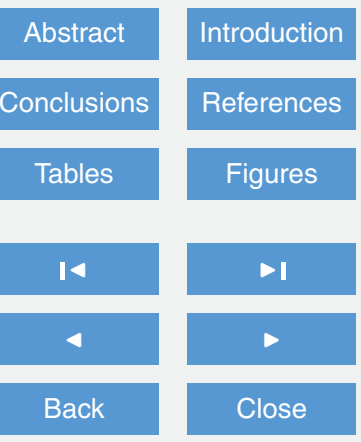

Full Screen / Esc

Printer-friendly Version

Interactive Discussion 


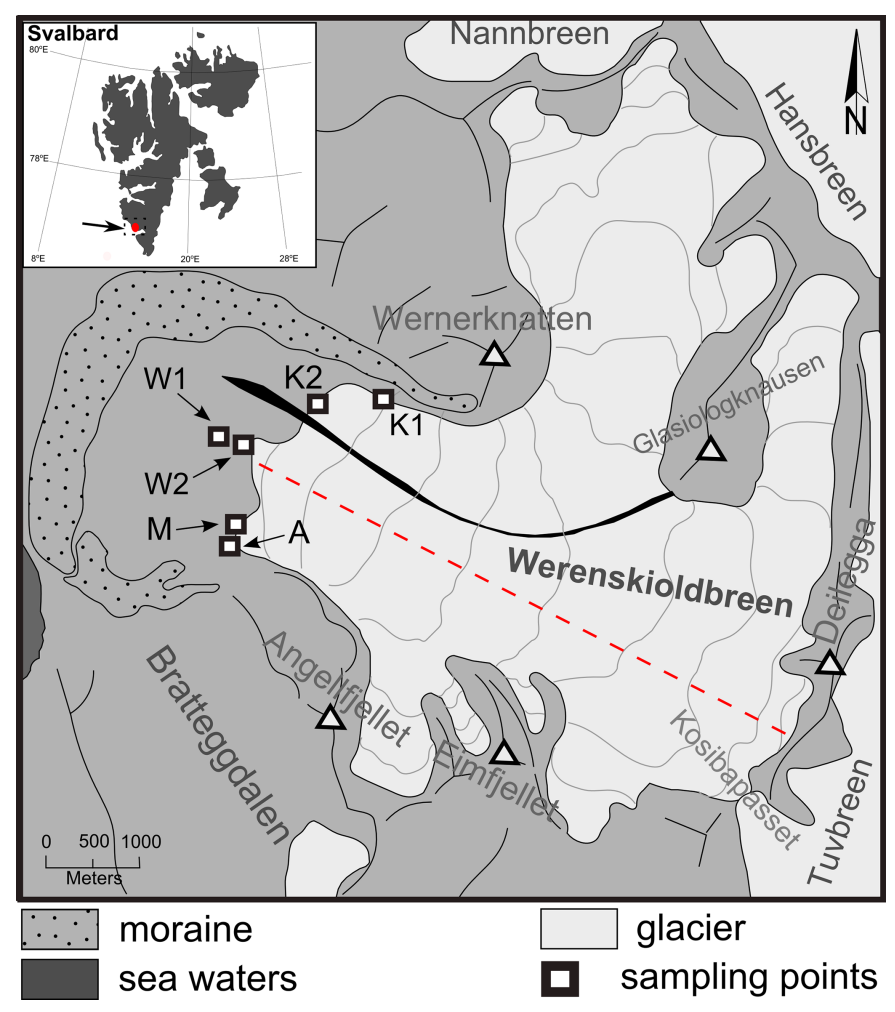

Figure 2. Location of Werenskioldbreen in whose forefield most of the reported radon measurements were performed. The red line indicates location of the glacier longitudinal profile presented on the Fig. $1 \mathrm{~b}$.

\section{TCD}

9, 2013-2052, 2015

Overview on radon measurements in

Arctic glacier waters

A. Kies et al.

\section{Title Page}

Abstract

Introduction

Conclusions References

Tables

Figures

14

4

Back

Close

Full Screen / Esc

Printer-friendly Version

Interactive Discussion 


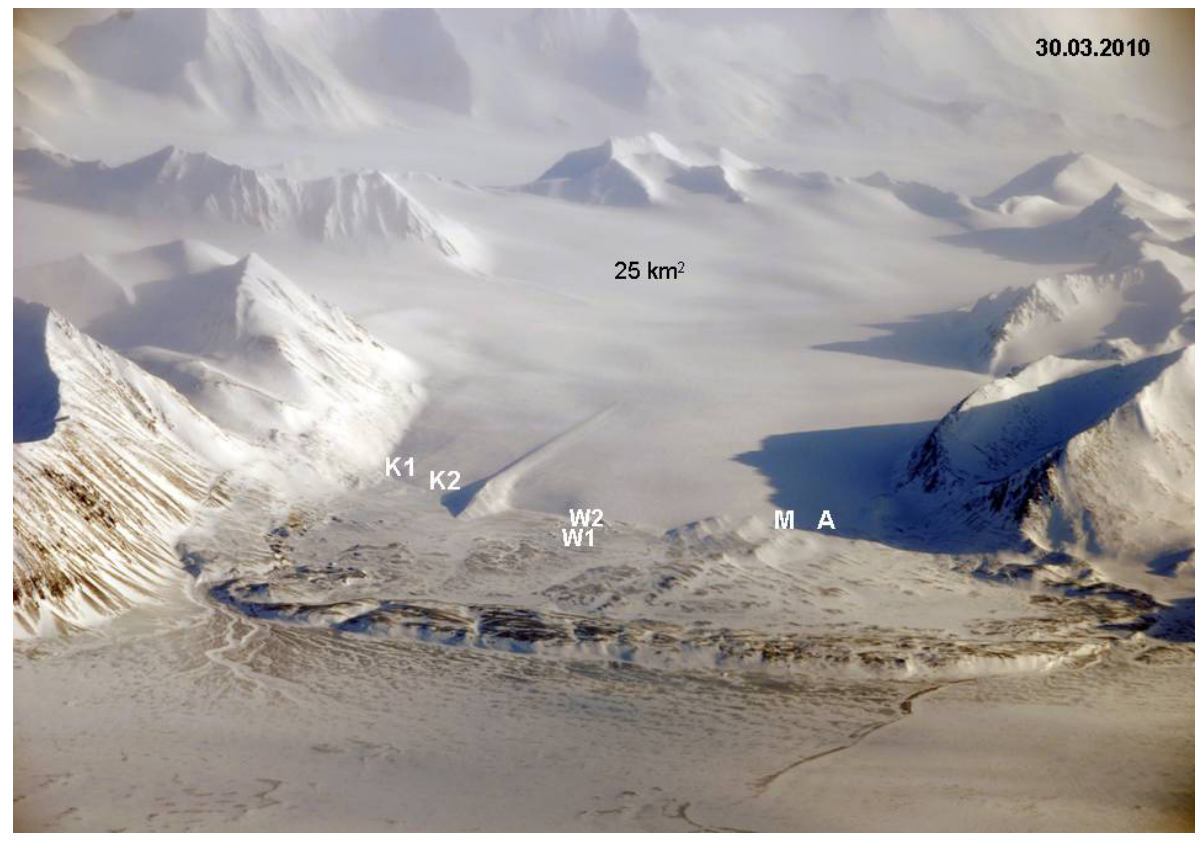

\section{TCD}

\section{9, 2013-2052, 2015}

\section{Overview on radon} measurements in Arctic glacier waters

A. Kies et al.

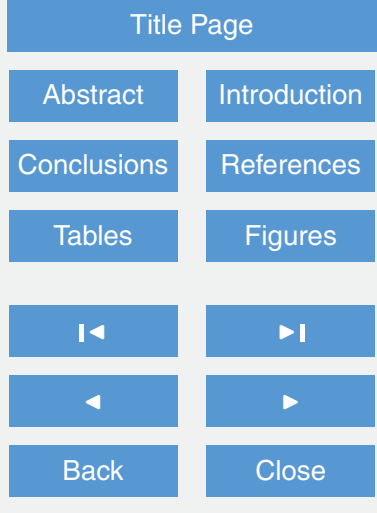

Full Screen / Esc

Figure 3. Werenskiold glacier with indicated sampling locations. (Photo A. Kies).

Printer-friendly Version

Interactive Discussion

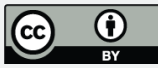




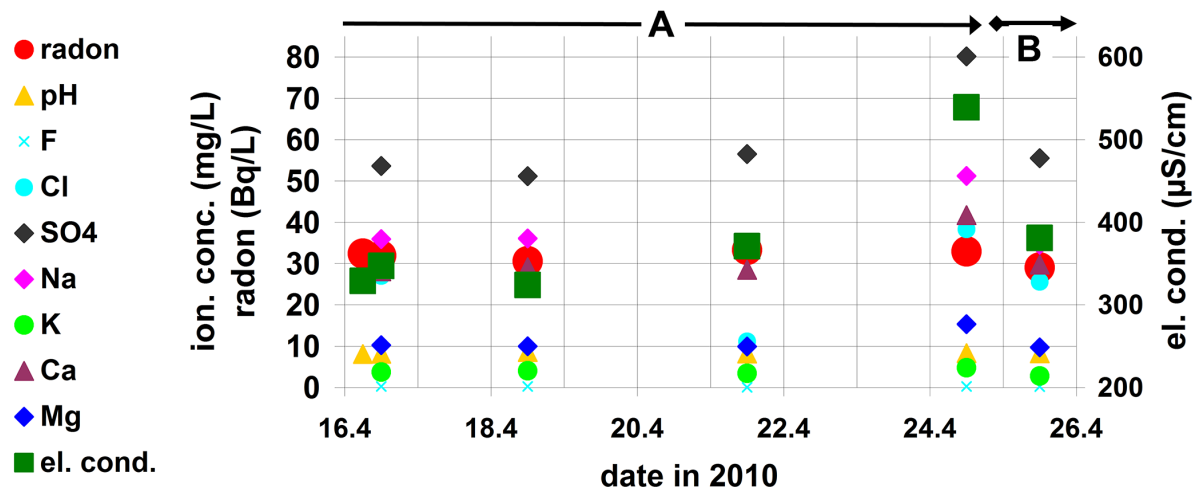

Figure 4. Example of variation of radon, conductivity and ion concentration prior to the freezing of an outflow $A$ and in a newly active outflow B; whereas all parameters changed, radon remained at the same level.

\section{TCD}

\section{9, 2013-2052, 2015}

Overview on radon measurements in

Arctic glacier waters

A. Kies et al.

\section{Title Page}

Abstract

Introduction

Conclusions

References

Tables

Figures

14

4

Back

Close

Full Screen / Esc

Printer-friendly Version

Interactive Discussion 


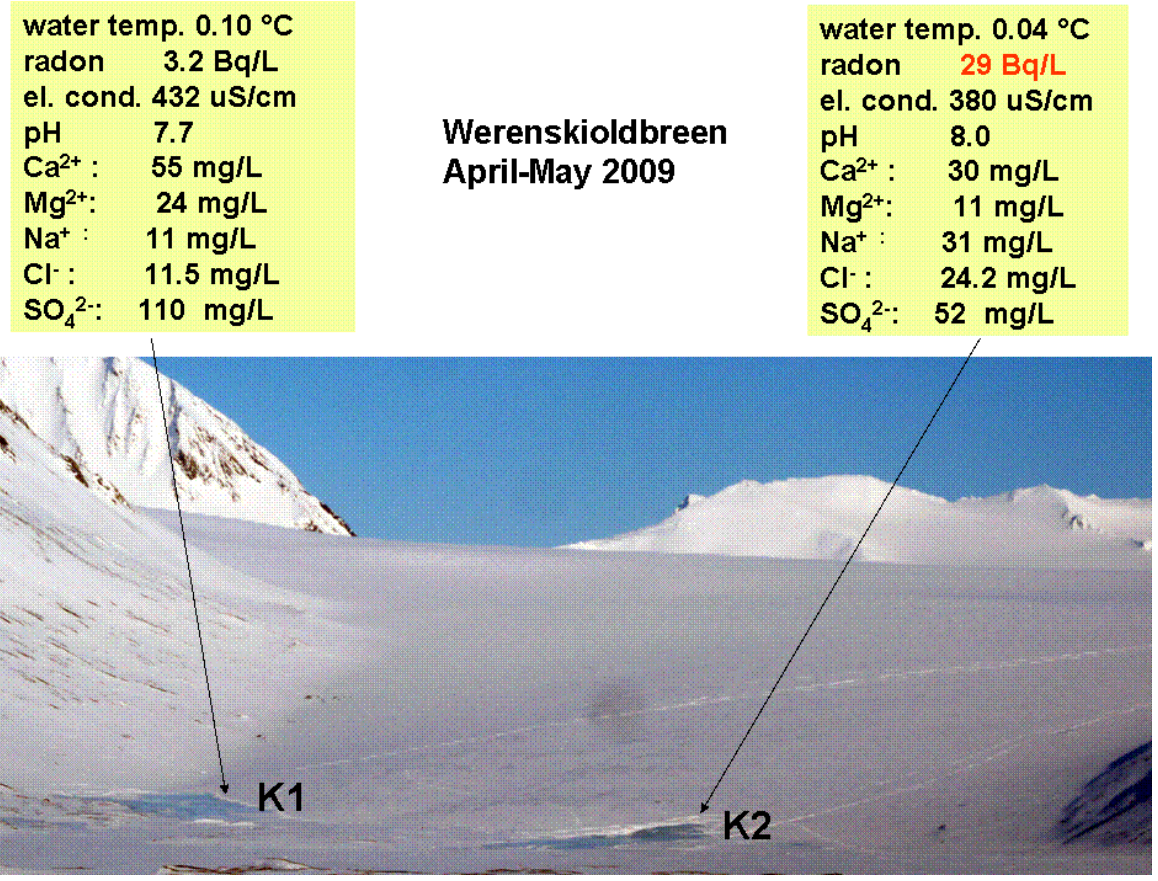

Figure 5. An example of the mean values of radon measurements done on the two outflows K1 (left) and K2 (right) in the ablation period 2009. Only at K2 a direct outflow on the lower slope of the glacier could be sampled, whereas in $\mathrm{K} 1$ running water was accessed under an ice cover. Radon concentrations allow differentiating between the two waters. (Photo A. Kies April 2009).

\section{TCD}

9, 2013-2052, 2015

Overview on radon measurements in

Arctic glacier waters

A. Kies et al.

\section{Title Page}

Abstract Introduction

Conclusions

14

4

Back

Full Screen / Esc

Printer-friendly Version

Interactive Discussion 


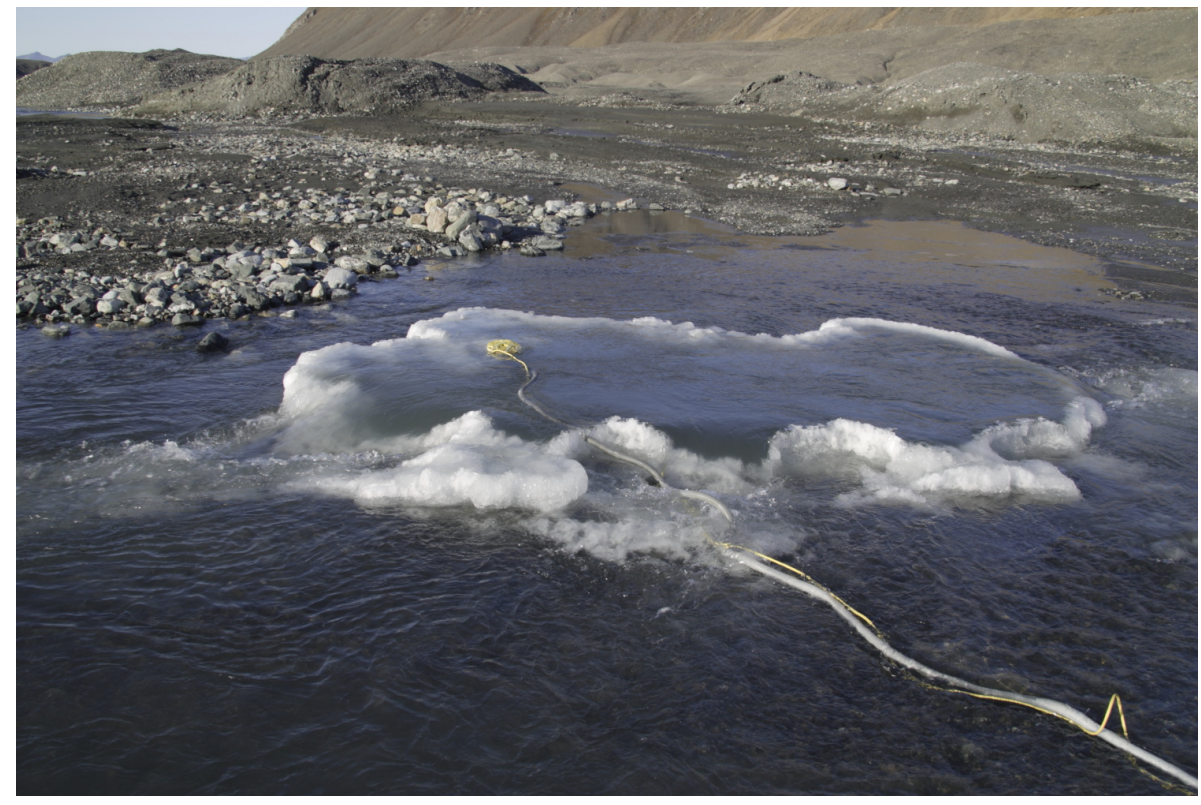

Figure 6. Radon, TDGP, EC and temperature measurements in the artesian W1 outflow at Werenskioldbreen forefield end of August 2009. Clearly seen is the ice rim around the outflow. (Photo O. Hengesch).

\section{TCD}

\section{9, 2013-2052, 2015}

Overview on radon measurements in Arctic glacier waters

A. Kies et al.

Title Page

\begin{tabular}{|c|c|}
\hline Abstract & Introduction \\
\hline Conclusions & References \\
\hline Tables & Figures \\
\hline I4 & $\triangleright$ I \\
\hline 4 & $\triangleright$ \\
\hline Back & Close \\
\hline Full Screen / Esc
\end{tabular}

Printer-friendly Version

Interactive Discussion 


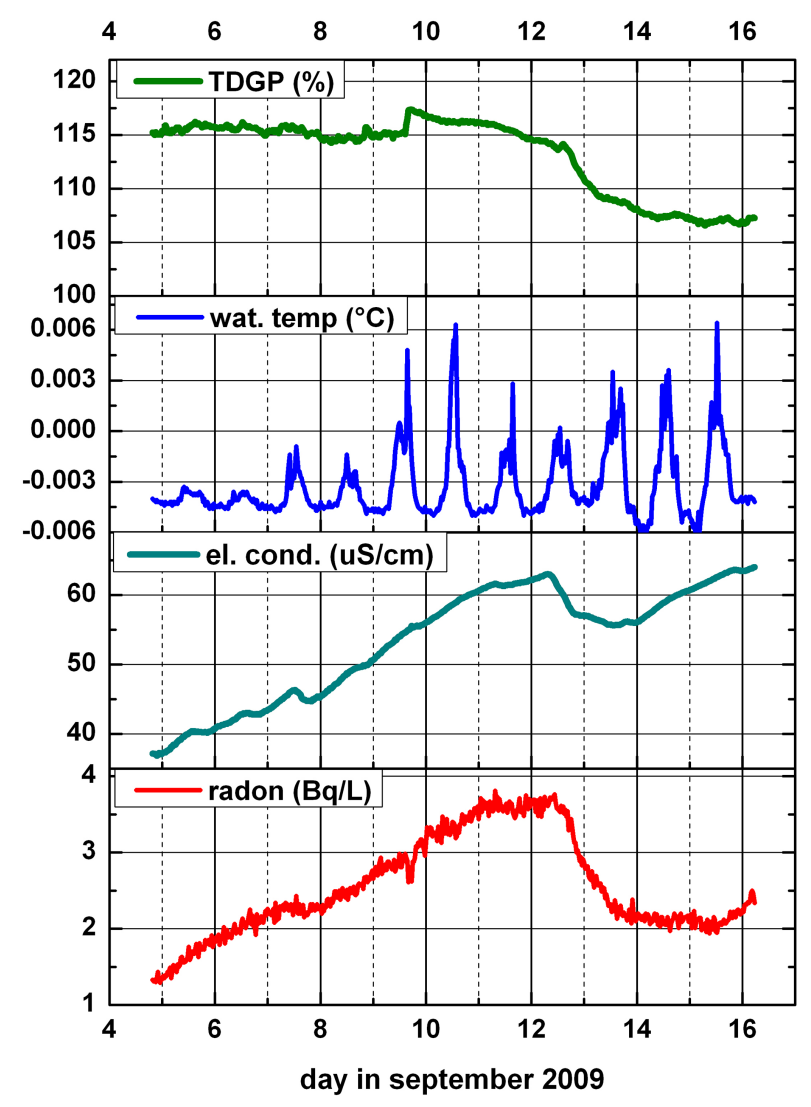

TCD

9, 2013-2052, 2015

Overview on radon measurements in

Arctic glacier waters

A. Kies et al.

\section{Title Page}

Abstract

Introduction

Conclusions

References

Tables

Figures

$1<$

4

Back

Close

\section{Full Screen / Esc}

Printer-friendly Version

Figure 7. Continuous measurements of radon, EC, temperature and TDGP in September 2009 at the artesian outflow W1 on Werenskioldbreen.

Interactive Discussion 


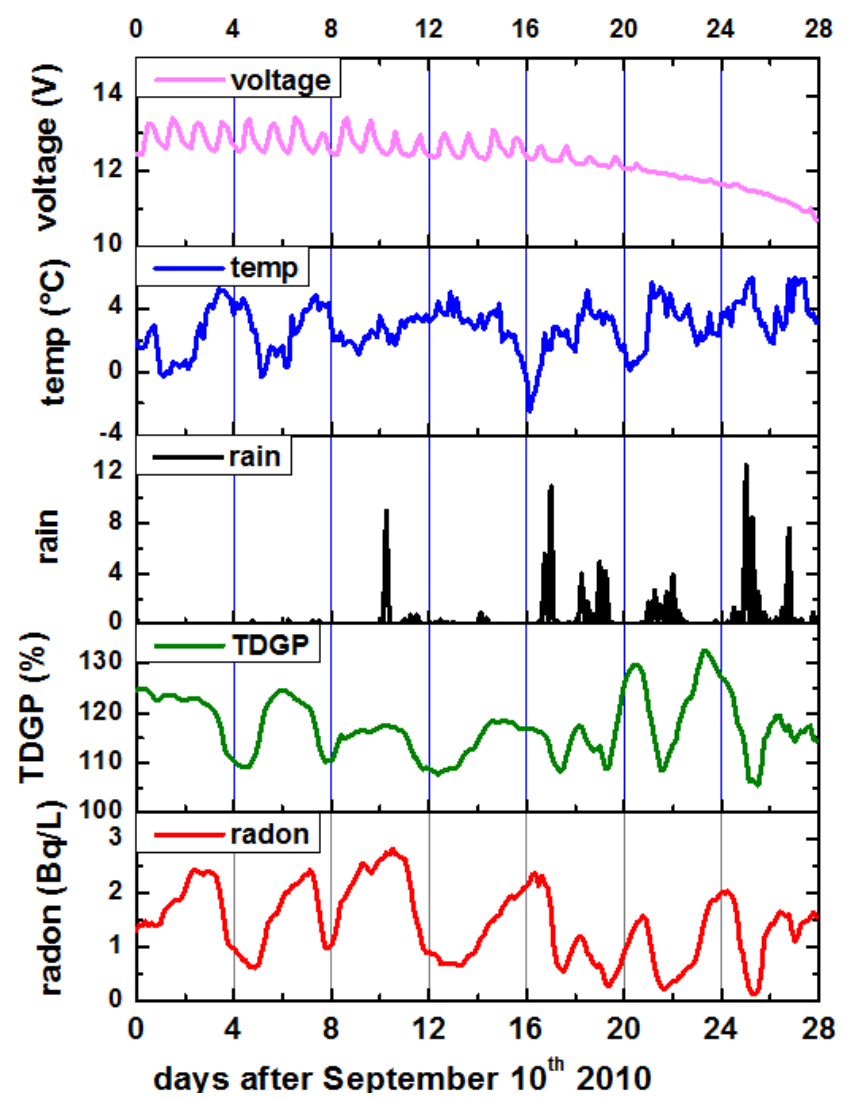

Figure 8. Radon, TDGP measured at the artesian outflow $\mathrm{W} 1$; temperature and rain were measured at the HPPS; the voltage of the battery gives a hint on the irradiative energy input to the glacier.

\section{TCD}

9, 2013-2052, 2015

Overview on radon measurements in

Arctic glacier waters

A. Kies et al.

Title Page

Abstract

Introduction

Conclusions

References

Tables

Figures

14

4

Back

Close

Printer-friendly Version

Interactive Discussion 


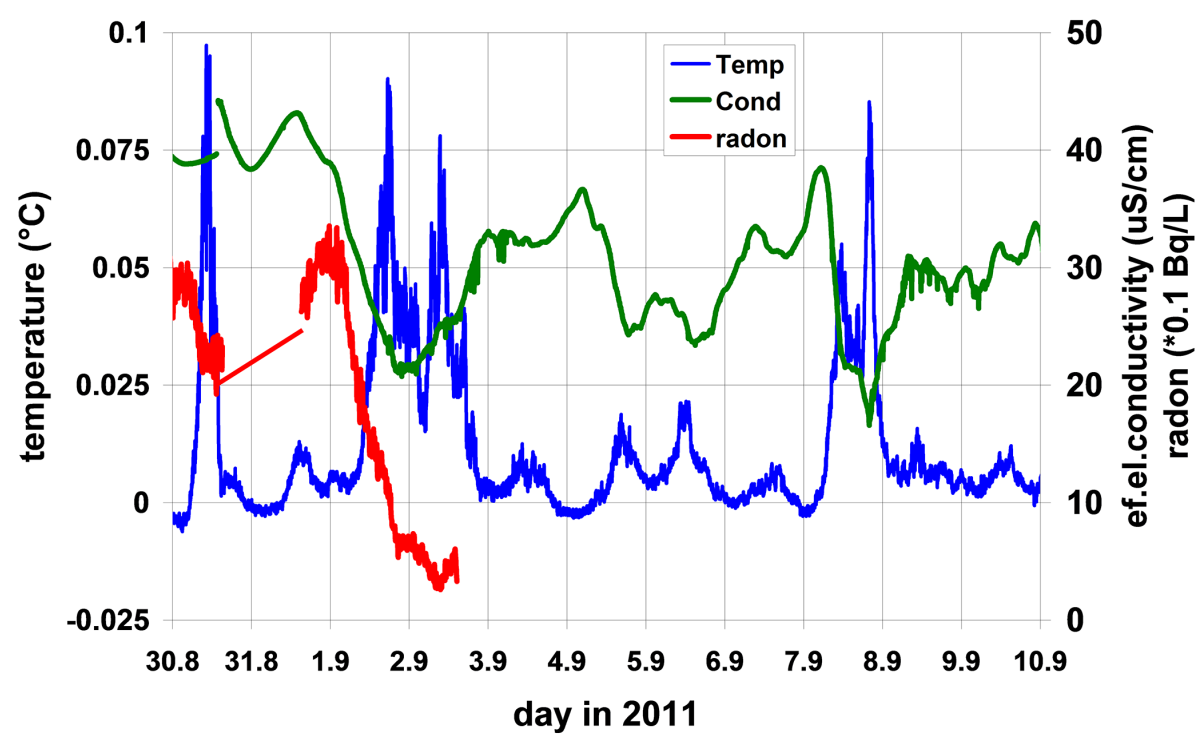

Figure 9. Autumn measurements at the 2011 newly formed the artesian outflow W2. Extreme weather conditions paired with an unexpected increase in discharge destroyed the radon measuring unit.

\section{TCD}

9, 2013-2052, 2015

Overview on radon measurements in

Arctic glacier waters

A. Kies et al.

\section{Title Page}

Abstract

Introduction

Conclusions

References

Tables

Figures

14

4

Back

Close

Printer-friendly Version

Interactive Discussion

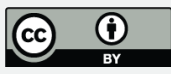




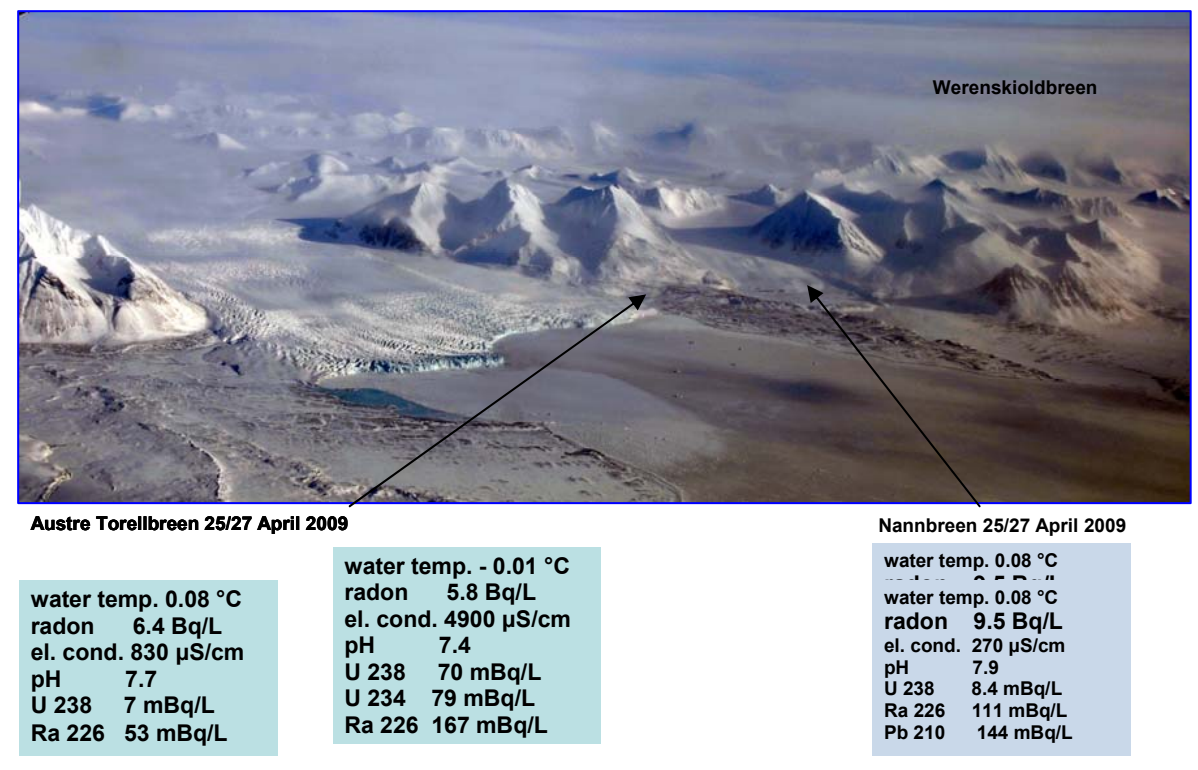

\section{TCD}

9, 2013-2052, 2015

Overview on radon

measurements in

Arctic glacier waters

A. Kies et al.

Title Page

\begin{tabular}{|c|c|}
\hline Abstract & Introduction \\
\hline Conclusions & References \\
\hline Tables & Figures \\
\hline & \\
\hline I & $\diamond$ \\
\hline 4 & $\triangleright$ \\
\hline Back & Close \\
\hline Full Screen / Esc \\
\hline
\end{tabular}

Figure 10. Example of measurements on two glaciers close to Werenskioldbreen in April 2009. (Photo A. Kies, April 2009).

Printer-friendly Version

Interactive Discussion 